\title{
Indoor thermal environments in Chinese residential buildings responding to the diversity of climates
}

Article

Accepted Version

Creative Commons: Attribution-Noncommercial-No Derivative Works 4.0

Li, B., Du, C., Yao, R., Yu, W. and Costanzo, V. (2018) Indoor thermal environments in Chinese residential buildings responding to the diversity of climates. Applied Thermal Engineering, 129. pp. 693-708. ISSN 1359-4311 doi: https://doi.org/10.1016/j.applthermaleng.2017.10.072 Available at https://centaur.reading.ac.uk/73225/

It is advisable to refer to the publisher's version if you intend to cite from the work. See Guidance on citing.

Published version at: http://www.sciencedirect.com/science/article/pii/S135943111732923X

To link to this article DOI: http://dx.doi.org/10.1016/j.applthermaleng.2017.10.072

Publisher: Elsevier

All outputs in CentAUR are protected by Intellectual Property Rights law, including copyright law. Copyright and IPR is retained by the creators or other copyright holders. Terms and conditions for use of this material are defined in the End User Agreement.

www.reading.ac.uk/centaur 
Central Archive at the University of Reading

Reading's research outputs online 
Applied Thermal Engineering 129 (2018) 693-708

Research Paper

Indoor thermal environments in Chinese residential buildings responding to the diversity of climates

3 Submitted Manuscript

Indoor thermal environments in Chinese residential buildings responding

\section{to the diversity of climates}

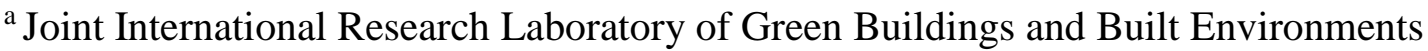

9 (Ministry of Education), Chongqing University, Chongqing 400045, China

${ }^{\mathrm{b}}$ National Centre for International Research of Low-carbon and Green Buildings (Ministry

${ }^{c}$ School of the Built Environment, University of Reading, Reading RG6 6AW, UK

*Corresponding author: r.yao@cqu.edu.cn; r.yao@ reading.ac.uk

\section{Abstract}


affects indoor thermal environment and the occupants' thermal response. This paper analyzes quantitatively the data from a large-scale field study across the country conducted from 2008 to 2011 in residential buildings. The study covers nine typical cities located in the five climate zones including Severe Cold (SC), Cold (C), Hot Summer and Cold Winter (HSCW), Hot Summer and Warm Winter (HSWW) and Mild (M) zones. It is revealed that there exists a large regional discrepancy in indoor thermal environment, the worst performing region being the HSCW zone. Different graphic comfort zones with acceptable range of temperature and humidity for the five climate zones are obtained using the adaptive Predictive Mean Vote (aPMV) model. The results show that occupants living in the poorer thermal environments in the HSCW and HSWW zones are more adaptive and tolerant to poor indoor conditions than those living in the north part of China where central heating systems are in use. It is therefore recommended to develop regional evaluation standards of thermal environments responding to climate characteristics as well as local occupants' acclimatization and adaptation in order to meeting dual targets of energy conservation and indoor thermal environment improvement.

Keywords: climate zones, residential buildings, large-scale survey, thermal environment differences, adaptive thermal comfort zones

\section{Introduction}

It is widely acknowledged that buildings account for more than $30 \%$ of total final energy consumption in the world and are responsible for consuming 35\%-40\% in the developed countries[1, 2], among which $30-60 \%$ are for improving indoor thermal environment in buildings[3]. In China, the building energy consumption has increased by $45 \%$ in two decades[4]. The proportion of building energy consumption was about $27.5 \%$ in 2001[5] and it was up to $36 \%$ (i.e. construction and operation) in 2014 [3]. With China's prosperous economy and growing urbanization rate, the Chinese governments have to, on the one hand, implement the total energy use control to limit the building energy consumption in operation under 1.1 billion tce (23\%)[3], and on the other hand ensure a much healthy and comfortable 
indoor environment. In such case, the central and local governments have been paying great attention in last years. The implementation of sustainable development strategies aimed at cutting carbon intensity per GDP unit of 60-65\% by 2030 based on 2005 levels[6], goes together with the issue of a series of buildings energy efficiency policies[7-9]. Meantime, improving people's living environment for health and well-being has become government's agenda[10]. Thus it poses great challenges to balance the demand between the energy consumption conservation and thermal comfort improvement in the built environment in China.

China covers a vast territory with five climate zones for building thermal design purpose, known as the 'Severe Cold' (SC), 'Cold' (C), 'Hot Summer Cold Winter' (HSCW), 'Hot Summer Warm Winter' (HSWW) and 'Mild' (M) zones[11]. There exists diverse characteristics in terms of climate and indoor thermal environments, as well as occupants' thermal perception on environments in the different zones[12-15]. The main question to be answered is thus: how the buildings and their environmental systems can be designed and operated in the way of balancing the energy and thermal comfort demands considering the regional climate characteristics and residents' habitat?

To answer this question, it is essential to gain a comprehensive understanding of the discrepancies in the indoor thermal environments and occupants' thermal responses in different climates. In the past decades, many researchers have conducted studies on indoor thermal environments and comfort in different regions in China and showed some useful and common knowledge. The main findings can be summarized saying that the indoor thermal environments differ with local indoor and outdoor climate in different climate zones and people' thermal sensation and the neutral temperatures (i.e. those temperatures drawn with occupants' thermal sensation of zero according to ASHRAE Standard 55[16]) vary in different climate zones [12-15, 17, 18] due to physiological[19, 20] and psychological adaptation[19, 21, 22]. For example, a field survey of residential buildings in summer and winter covered nine cities from 1998 to 2004 conducted by Yoshino et al.[12] highlighted a great diversity in indoor thermal environments between the northern and southern China. However, the sample 
size was very limited only in several homes; furthermore, the measuring duration were just in one week continuously in summer and winter respectively. A recent field study[23] of three climate zones was conducted in winter but focused more on thermal adaptation. The results indicated that in Shanghai occupants had better adaptation to cold due to the lack of space heating while Harbin occupants were used to warmer indoors. With the similar thought, a study from Yan et al.[18] concentrated on the thermal environments in the four zones of eastern China, further developed the adaptive models in the different zones. This study covered the 120 residential buildings in 12 cities and the results demonstrated the regression coefficients in HSCW zone $(0.326 / \mathrm{K})$ and in HSWW zone $(0.554 / \mathrm{K})$ were significant higher than that in SC zone $(0.12 / \mathrm{K})$ and $\mathrm{C}$ zone $(0.271 / \mathrm{K})$ in free running buildings, suggesting the neutral temperatures are affected by outdoor climates evidently. However, this study was just conducted in the summer time of 2005(July and August) and the winter time (January and February in 2006) while the occupants' thermal adaptation failed to be analyzed from the view of the whole year. Overall, regardless of these studies, it is worthwhile to mention that the majority of field studies had focused on the limited regions, covering just one or more climate zones, and the differed research methods and periods made it less comparable between different climate zones. More importantly, the majority of the cross-section are concentrated mainly on summer and winter rather than the annual investigation on thermal environments, and the sample size is limited to reflect the long-term thermal adaptation of occupants over the year, due to the difficulty of on-site surveys. Moreover, most studies for free running buildings focused on building relationships between the comfort temperatures and outdoor temperatures, i.e., developing the adaptive models[16, 24]. Thanks to the update and implementation of the new building design standards in China (e.g. demands improvement for building envelope in JGJ 134-2001[25] and JGJ 134-2010[26] respectively for HSCW zone) and the building refurbishment, the building indoor thermal environments have been improved to great degree. Therefore, there is a need to fill the knowledge gap of the most recent information of the annual indoor thermal environment conditions and human thermal perceptions covering the five different climate zones comprehensively. 
To the authors' knowledge, few studies of on-site surveys are available in a large-scale nationwide range (e.g., covering the five climate zones over the same period), a large sample size (e.g., covering a larger number of building cases with thermal environment tests and questionnaire surveys simultaneously), and a long-term measurement (e.g., covering the 12month tests annually). Accordingly, the present paper aims to examine more in depth these differences by presenting the outcomes of a new large-scale nationwide field study on indoor thermal environment and thermal comfort in residential buildings covering the five climate zones. A special attention is paid to identify the discrepancies of the real annual indoor environmental conditions and occupants' acceptable comfort zones considering the long-term adaptation to local environments. This will provide scientific evidence to support the concept of climate responsive building design pertinently by evaluating thermal comfort conditions, meantime provide references to find a good tradeoff between energy saving potential and wellbeing requirements.

\section{Methodology}

\subsection{Study selection and data extraction}

A nationwide field study had been conducted from 2008 to 2011 in the five climate zones of China. The surveyed buildings were located in the nine typical cities of Shenyang and Harbin in SC zone, Xi'an in C zone, Chongqing, Wuhan and Chengdu in HSCW zone, Fuzhou and Guangzhou in HSWW zone and Kunming in the $\mathrm{M}$ zone, respectively. On-site field measurements and subjective questionnaire surveys were carried out monthly in each city around the year, thus populating a database including the initial sample capacity over 20,000 cases of the annual indoor thermal environments and occupants' thermal perceptions.

It is however worth noting that all the investigated buildings located in the two northern climates (i.e., in the SC and C zones) were supplied with urban central heating systems in winter which are not operable for occupants.

During the survey, the thermal environments measurements and the questionnaire survey were conducted both in AC and non-AC buildings. Therefore, the daily life was not disturbed and 
128 they could use any heating and cooling devices. Overall, the initial sample size was almost

12921,000 . Screening for cases with free running condition was just conducted in this study. The

130 data used for the analysis of the free-running residential buildings coming from the non-AC

131 used situation with the data size of nearly 16,500 .

132 After the first screening, the total number of valid samples are 16458, including 3040 from 133 Severe Cold zone (18.4\%), 1410 from Cold zone (8.6\%), 6154 from the Hot Summer and Cold 134 Winter zone (37.4\%), 3820 from the Hot Summer and Warm Winter Zone (23.2\%) and 2034 135 from Mild zone (12.4\%). Table 1 presents the information about sample sizes in each city. To 136 simplify, we categorized the cases into four seasons (spring: March, April, May; summer: June, 137 July, August; autumn: September, October, November; winter: December, January, February).

138 It is observed that except some special cases in some periods, basically the sample size for 139 each season is uniformly distributed in each study city.

140 Table 1. Survey data and validity analysis results

\begin{tabular}{|c|c|c|c|c|c|c|c|}
\hline Climate Zones & Cities & $\begin{array}{c}\text { Spring } \\
\text { (Mar-May) }\end{array}$ & $\begin{array}{l}\text { Summer } \\
\text { (Jun-Aug) }\end{array}$ & $\begin{array}{c}\text { Autumn } \\
\text { (Sep-Nov) }\end{array}$ & $\begin{array}{c}\text { Winter } \\
\text { (Dec-Feb) }\end{array}$ & Sum & $\begin{array}{l}\text { Valid } \\
\text { data\% }\end{array}$ \\
\hline \multirow{2}{*}{ Severe Cold (SC) } & Shenyang & 555 & 541 & 575 & 569 & 2240 & 100 \\
\hline & Harbin* & 0 & 400 & 310 & 90 & 800 & 99.5 \\
\hline Cold $(C)$ & Xi'an* & 404 & 292 & 346 & 368 & 1410 & 100 \\
\hline \multirow{3}{*}{$\begin{array}{c}\text { Hot Summer Cold } \\
\text { Winter }(\text { HSCW })\end{array}$} & Chongqing & 570 & 461 & 458 & 584 & 2073 & 97 \\
\hline & Wuhan & 501 & 343 & 525 & 468 & 1837 & 95 \\
\hline & Chengdu & 606 & 555 & 487 & 596 & 2244 & 96.7 \\
\hline Hot Summer Warm & Fuzhou & 492 & 370 & 469 & 517 & 1848 & 97.5 \\
\hline Winter $(H S W W)$ & Guangzhou & 550 & 407 & 487 & 528 & 1972 & 94.4 \\
\hline $\operatorname{Mild}(M)$ & Kunming & 589 & 583 & 566 & 296 & 2034 & 98.6 \\
\hline Total samples & & & & & & 16458 & 97.5 \\
\hline
\end{tabular}
October. 


\subsection{Questionnaire design}

A questionnaire was designed in three parts to quantify the information regarding i) buildings' characteristics (including building location, construction age, orientation, type of surveyed room and floor areas, window type and HVAC equipment if present); ii) respondents' personal information; iii) thermal environments measurement and subjective thermal responses in responding to the thermal environments during the test period. As for the last ones, the physical parameters included indoor and outdoor air temperatures, relative humidity and air velocity measurements taken by testers. The questionnaire used for summer survey is provided in Appendix for guidance.

During the survey respondents reported their clothing ensembles at the time of completing the questionnaire by means of a clothing checklist. Then the values of clothing insulation were estimated in 'clo' units based on ISO 9920[27] when doing analysis. The metabolic rate was transferred to values according to ASHRAE 55[16] (seated: 1.0met, standing: 1.1met, walking: 1.2met), too.

As for the respondents' subjective thermal perceptions, their thermal sensation was measured by the ASHRAE 55 seven-point thermal sensation scale[16]: -3 cold, -2 cool, -1 slightly cool, 0 just right (neutral), 1 slightly warm, 2 warm and 3 hot. Humid and air movement sensation were also evaluated by 7-point scales (humid sensation: -3 too dry, -2 dry, -1 slight dry, 0 comfort, 1 slight humid, 2 humid, 3 too humid; air movement sensation: -3 too still, -2 still, 1 slight still, 0 comfort, 1 slight windy, 2 windy, 3 too windy). The thermal expectation for indoor thermal environments were investigated using the question 'At this point in time, would you prefer to change temperature/ air humidity/ air velocity: -1 lower, 0 no change, 1 upper?'. More detailed as for the subjective questionnaires has been given in Appendix for reference.

\subsection{Buildings information}

Table 2 summarizes the basic information of the investigated buildings. It is clearly seen that more than half of the residential buildings in Cold zone were built before 1990s (51.5\%), i.e., before the first national building codes came into force, and this contributed to a high 


\begin{tabular}{|c|c|c|c|c|c|c|c|c|c|}
\hline \multirow[b]{2}{*}{$\begin{array}{c}\text { Climate } \\
\text { Zones }\end{array}$} & \multicolumn{3}{|c|}{$\begin{array}{c}\text { Construction ages } \\
(\%)\end{array}$} & \multicolumn{3}{|c|}{ Construction type (\%) } & \multicolumn{3}{|c|}{ Windows type (\%) } \\
\hline & $\begin{array}{l}\text { before } \\
90 \mathrm{~s}\end{array}$ & $90 \mathrm{~s}$ & $\begin{array}{l}\text { after } \\
90 \mathrm{~s}\end{array}$ & brick-concrete & $\begin{array}{l}\text { reinforced } \\
\text { concrete }\end{array}$ & other & $\begin{array}{c}\text { single } \\
\text { frame, } \\
\text { single } \\
\text { glass }\end{array}$ & $\begin{array}{c}\text { single } \\
\text { frame, } \\
\text { double } \\
\text { glass }\end{array}$ & $\begin{array}{c}\text { double } \\
\text { frame, } \\
\text { double } \\
\text { glass }\end{array}$ \\
\hline SC Zone & 10.50 & 46.10 & 43.40 & 33.10 & 66.90 & & 18.90 & 70.90 & 10.20 \\
\hline C Zone & 51.50 & 30.10 & 18.40 & 53.40 & 38.30 & 8.30 & 75.60 & 13.90 & 10.50 \\
\hline HSCW Zone & 15.30 & 35.80 & 48.90 & 37.80 & 61.90 & 0.30 & 81.20 & 10.20 & 8.60 \\
\hline HSWW Zone & 18.60 & 39.50 & 41.90 & 18.80 & 80.00 & 1.20 & 73.60 & 19.30 & 7.10 \\
\hline M Zone & 6.70 & 38.90 & 54.40 & 4.60 & 95.40 & & 84.50 & 15.50 & 0.00 \\
\hline
\end{tabular}

proportion of buildings with brick-concrete structures (53.4\%). Except the $\mathrm{C}$ zone, the majority of the buildings in the remaining four zones were constructed in the 1990s and thereafter, with the proportion of more than $70 \%$. The proportion of buildings built in the 1990s was slightly smaller than that after 1990s except SC zones. In addition, most of these buildings were constructed by using reinforced concrete $(66.9 \%$ in the SC zone, $61.9 \%$ in the HSCW zone, $80 \%$ in HSWW zone and $95.4 \%$ in M zone respectively).

As for the window types in Table 2, they differed between SC zone and the remaining four zones due to climate differences. In fact, around $71 \%$ of the buildings were provided with single frame and double-glazing windows in SC zone to protect against thermal losses, while in the other zones windows with single frame and single-glazing were dominant (above 70\%).

(1)

183 
$+85^{\circ} \mathrm{C}$, accuracy: $\pm 0.5^{\circ} \mathrm{C}$; humidity range: 0-100 \%, accuracy: $\pm 2 \%$, Dwyer Company, U.S) and the Testo-425 hot-wire anemometer (range: $0-20 \mathrm{~m} / \mathrm{s}$, accuracy: $\pm 0.03 \mathrm{~m} / \mathrm{s}+5 \%$ of measured values, Testo Company) were used during the survey.

The indoor thermal environment measurements were conducted by testers and the probes of the instruments were placed 0.5 far away from respondents and at the height of $0.6 \mathrm{~m}$ above the floor for seated respondents and of $1.1 \mathrm{~m}$ for standing respondents. For outdoor measurements, the same instruments were set with sufficient distance from the investigated buildings, at a height of $1.1 \mathrm{~m}$ above the ground.

All these instruments were calibrated before each survey and the accuracies were complied with the prescriptions of the ISO 7726[28]. To ensure good measurement accuracy, the measuring time for each parameter continued for more than $5 \mathrm{~min}$ and the measurements were repeated three times to ensure the steady-state condition (ASHRAE 55[16]). The averaged values of the parameters from the three-time measures were used for each corresponding case in the thermal environment analysis presented in the Results section.

\subsection{Data processing}

Before further analyses, preliminary tests aimed at checking for data integrity, validity and reliability were carried out to ensure the data quality. Reliability test was to find the potential contradictory answers in the questionnaires. Taking questions 7 and 8 of questionnaire in Appendix as an example, if respondents expected to increase the indoor air temperatures related to Q7 but meantime they are using the air-conditioning system in the cooling mode (Q8), the contrary answer would be regarded as invalid and expunged from the analysis to make sure the respondents' thermal sensation are correctively consistent with their surroundings.

After this cleaning step, the bin method was adopted: outdoor air temperatures were firstly binned into one-degree $\left({ }^{\circ} \mathrm{C}\right)$ increment to count the frequency and average indoor air temperatures in each bin interval. Besides, considering that the indoor air temperature is the closest indicator of occupants' thermal responses, the indoor air temperatures were binned into 
one-degree intervals to analyze the respondents' mean thermal sensation votes corresponding to each temperature interval. The same method has also been used to analyze respondents' thermal preferences.

Finally, for all statistical modeling conducted on the sub-samples deriving from the bin process, each data point was weighted according to the number of respondents' questionnaire it resembled (i.e. the sample size within the bin).

\section{Results}

The outcomes of the field study are reported in the following first showing the relationship between indoor and outdoor temperatures for the surveyed residential buildings, then analyzing occupants' responses in terms of thermal sensation and thermal acceptability, and finally demonstrating the different comfort zones for the five climate zones.

\subsection{Comparison of thermal environments}

Given the great influence of outdoor conditions on indoor thermal environments for freerunning buildings, which would indirectly influence occupants' thermal comfort, the annual distribution of indoor and outdoor air temperatures during the field study in the five climate zones have been summarized in Table 3 on a monthly basis. It is possible to see that the outdoor temperatures in the $\mathrm{SC}$ zone have the largest range from $-17.8{ }^{\circ} \mathrm{C}\left(\mathrm{T}_{\text {out-min }}\right)$ on January to $34.4{ }^{\circ} \mathrm{C}\left(\mathrm{T}_{\text {out-max }}\right)$ on August, while the indoor temperatures span from $19.5{ }^{\circ} \mathrm{C}\left(\mathrm{T}_{\text {in-mean }}\right)$ on November to $28.1{ }^{\circ} \mathrm{C}$ on August ( $\mathrm{T}_{\text {in-mean }}$ ). The $\mathrm{C}$ zone presents a similar trend, with indoor temperatures on January and February being in the range of $18^{\circ} \mathrm{C}-24^{\circ} \mathrm{Cin}$ the design standard [29] for most of the time, due to the central heating systems in operation. By contrast, though the lowest mean outdoor temperatures in the HSCW zone on January is about $8.8^{\circ} \mathrm{C}$, the corresponding mean indoor temperature is similarly low (around $11.3{ }^{\circ} \mathrm{C}$ ) and close to the outdoor temperatures resulting from the poor building envelope performances. In summer, the maximum indoor and outdoor temperatures raise up to $38^{\circ} \mathrm{C}$ and $37.5^{\circ} \mathrm{C}$ respectively, showing a significant relation between indoor and outdoor climates. Similarly, the indoor temperature change in the HSWW zone are close to that in HSCW zone, while both the monthly indoor 
242 and outdoor temperatures are slightly higher. The M zone significantly differs from the other

243 four zones by showing moderate and more uniform indoor and outdoor temperatures

244 throughout the year. The fluctuations of mean air temperatures are in the range of $15.8{ }^{\circ} \mathrm{C}$ to

$24525.7^{\circ} \mathrm{C}$ for outdoor temperature and $15.1{ }^{\circ} \mathrm{C}$ to $25.5^{\circ} \mathrm{C}$ for indoor temperature respectively.

247 Table 3. Annual air temperature distribution of indoor and outdoor environments in each climate zone

\begin{tabular}{|c|c|c|c|c|c|c|c|c|c|c|}
\hline \multirow{2}{*}{ Month } & \multirow{2}{*}{ Climate } & \multicolumn{4}{|c|}{ Outdoor air temperature $\left({ }^{\circ} \mathrm{C}\right)$} & \multicolumn{4}{|c|}{ Indoor air temperature $\left({ }^{\circ} \mathrm{C}\right)$} & \multirow{2}{*}{ Cases } \\
\hline & & $\mathbf{T}_{\min }$ & $\mathbf{T}_{\max }$ & $\mathbf{T}_{\text {mean }}$ & SD & $\mathbf{T}_{\min }$ & $\mathbf{T}_{\max }$ & $\mathbf{T}_{\text {mean }}$ & SD & \\
\hline \multirow{5}{*}{ January } & SC zone & -19 & 1 & -8.4 & 0.23 & 12.5 & 27 & 21.0 & 0.16 & 197 \\
\hline & C zone & -2 & 1.7 & -1.0 & 0.05 & 15 & 25.3 & 19.9 & 0.13 & 172 \\
\hline & $\begin{array}{l}\text { HSCW } \\
\text { zone }\end{array}$ & -6 & 14.8 & 8.8 & 0.13 & 2 & 18 & 11.3 & 0.13 & 548 \\
\hline & $\begin{array}{l}H S W W \\
\text { zone }\end{array}$ & 4.3 & 28.2 & 15.4 & 0.23 & 8.2 & 28.4 & 16.0 & 0.2 & 334 \\
\hline & M zone & 10.2 & 21.1 & 15.8 & 0.36 & 8.9 & 17.2 & 13.8 & 0.22 & 98 \\
\hline \multirow{5}{*}{ February } & SC zone & -18 & 5 & -7.3 & 0.23 & 11 & 30 & 20.8 & 0.16 & 198 \\
\hline & C zone & 0.8 & 3 & 1.4 & 0.03 & 17 & 26.5 & 21.4 & 0.12 & 196 \\
\hline & $\begin{array}{l}\text { HSCW } \\
\text { zone }\end{array}$ & -3.7 & 18.9 & 11.2 & 0.23 & 3.5 & 20.2 & 14.3 & 0.14 & 542 \\
\hline & $\begin{array}{l}\text { HSWW } \\
\text { zone }\end{array}$ & 9.8 & 28.6 & 20.1 & 0.26 & 12.6 & 24.6 & 20.6 & 0.25 & 334 \\
\hline & M zone & 18.5 & 24.8 & 21.1 & 0.24 & 18.2 & 23.5 & 20.8 & 0.11 & 99 \\
\hline \multirow{5}{*}{ March } & SC zone & -7 & 15.5 & 3.42 & 0.39 & 15.7 & 25.1 & 20 & 0.14 & 191 \\
\hline & C zone & 0.8 & 14.5 & 2.6 & 0.06 & 19.6 & 24.6 & 22.3 & 0.3 & 145 \\
\hline & $\begin{array}{l}\text { HSCW } \\
\text { zone }\end{array}$ & 9 & 24 & 19.0 & 0.16 & 10 & 26.3 & 19.4 & 0.14 & 563 \\
\hline & $\begin{array}{l}\text { HSWW } \\
\text { zone }\end{array}$ & 12.6 & 29 & 20.6 & 0.19 & 12.7 & 23.6 & 21.6 & 0.56 & 346 \\
\hline & M zone & 11.7 & 24 & 18.4 & 0.27 & 15.3 & 23.3 & 20.4 & 0.11 & 200 \\
\hline
\end{tabular}




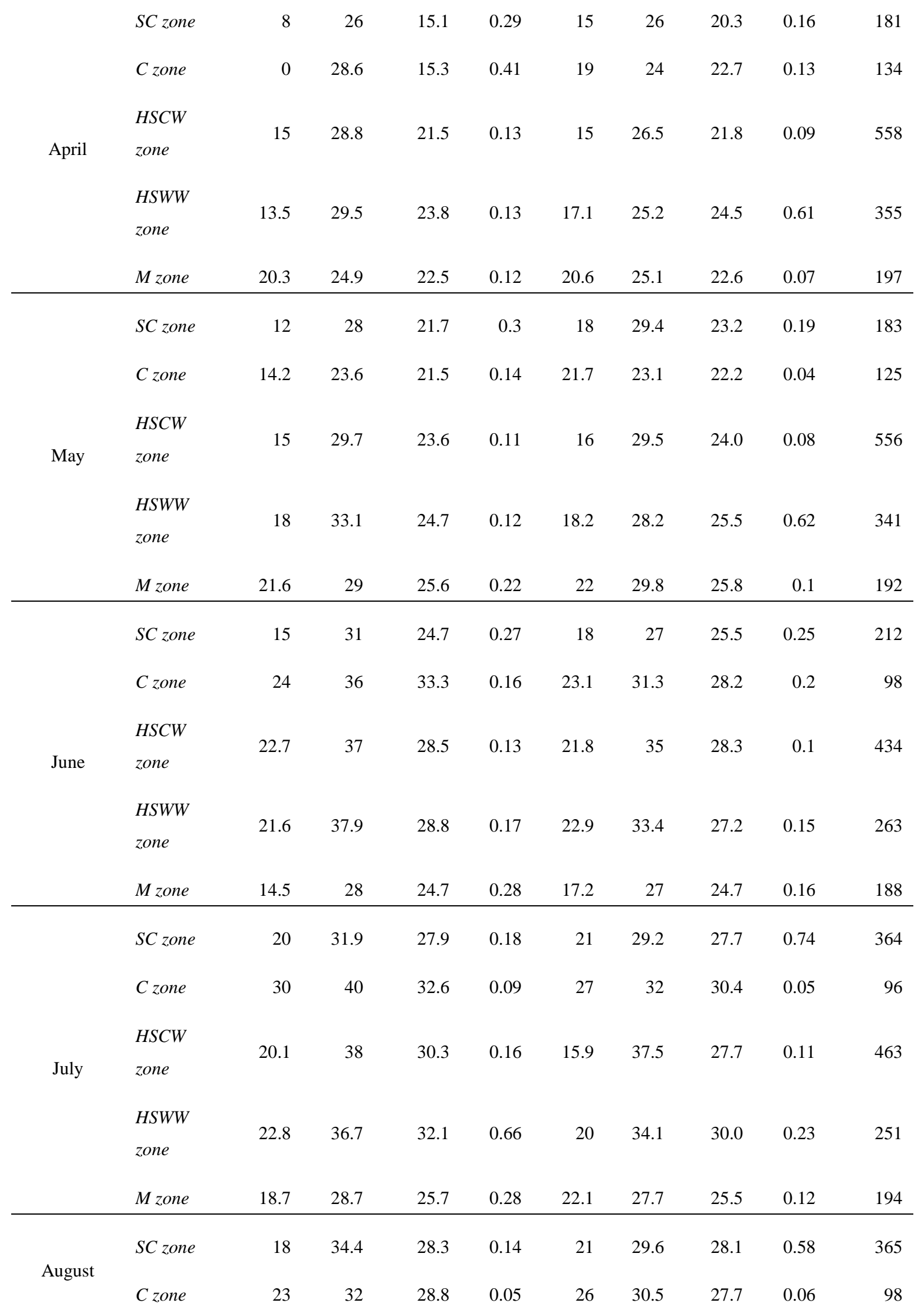




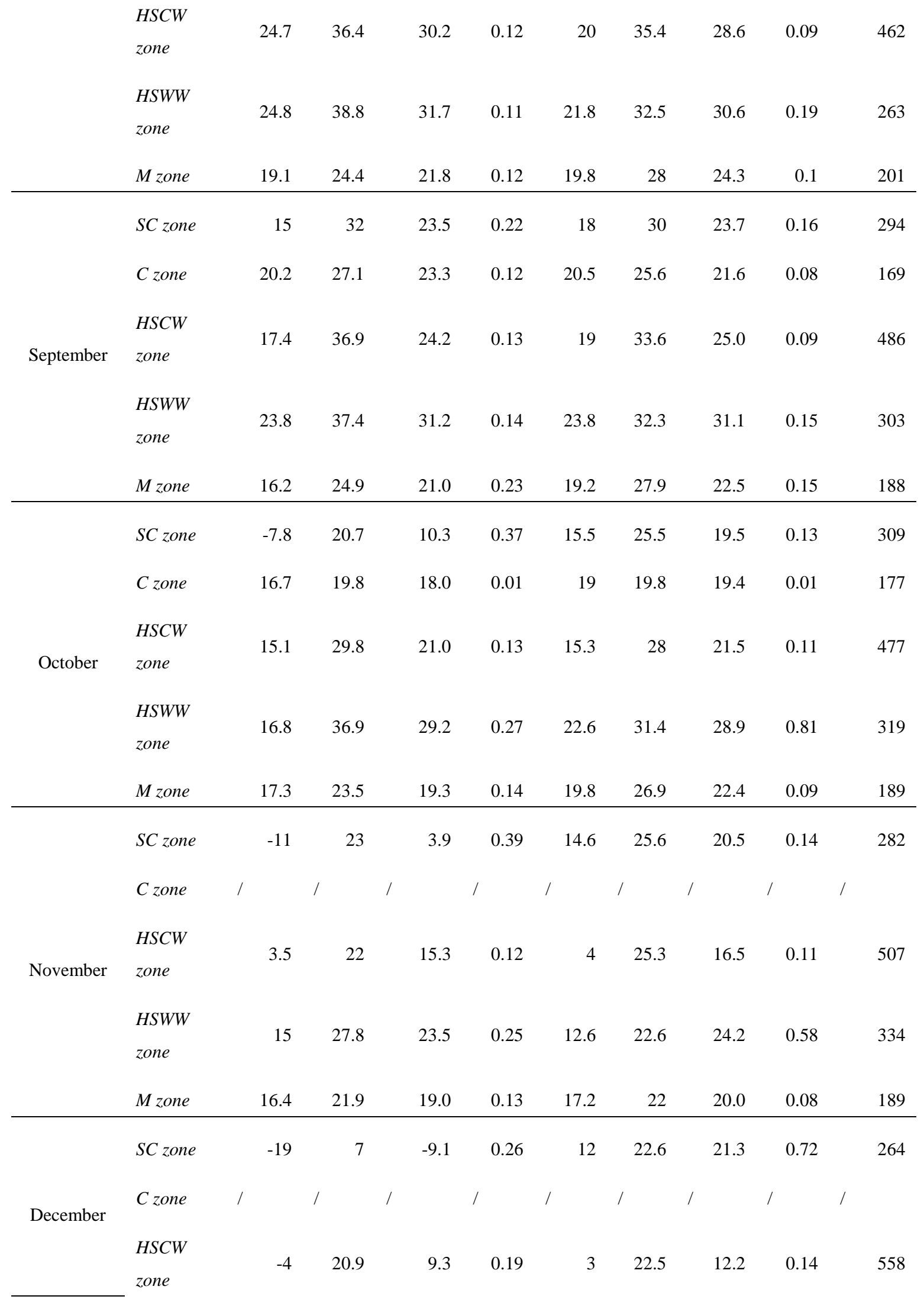




\begin{tabular}{lrrrrrrrrr}
$\begin{array}{l}\text { HSWW } \\
\text { zone }\end{array}$ & 10.1 & 29 & 18.5 & 0.23 & 10.3 & 20.5 & 18.9 & 0.19 & 377 \\
M zone & 10 & 23.6 & 15.8 & 0.45 & 12.5 & 18.6 & 15.1 & 0.14 & 99 \\
\hline
\end{tabular}

250 Figure 1 further demonstrates the relationship between indoor and outdoor temperatures in the 251 five climate zones. Here the area of the bubbles represents the sample size (i.e. the number of cases) pertaining to each indoor air temperature bin of $1^{\circ} \mathrm{C}$ size. Regression models between indoor and outdoor air temperatures for each zone are also presented in the figure with red lines. For the SC and $\mathrm{C}$ zones, the dotted red lines for the indoor temperature value of $18{ }^{\circ} \mathrm{C}$ marked the lowest set point of indoor air temperature for heating design. From Figure 1, in the two northern climate zones, the linear relations between indoor and outdoor temperature are found only out of the heating period and the indoor air temperatures seldom exceed $30{ }^{\circ} \mathrm{C}$. In winter, when the central heating systems are in operation, the indoor air temperatures are usually found to be above $20^{\circ} \mathrm{C}$, higher significantly than the designed set point, although the lower outdoor air temperatures are significantly under $10^{\circ} \mathrm{C}$ for $\mathrm{SC}$ zone and $15^{\circ} \mathrm{C}$ for $\mathrm{C}$ zone during the heating periods. By contrast, there are significant linear relationships between indoor and outdoor temperatures for residential buildings in the three southern climate zones, well demonstrated by the high values of the coefficient of determination from the statistical analysis $\left(\mathrm{R}^{2}=0.98\right.$ for HSCW zone, $\mathrm{R}^{2}=0.97$ for HSWW zone and $\mathrm{R}^{2}=0.93$ for $\mathrm{M}$ zone). As for the HSCW and HSWW zones, the annual indoor temperatures are more strongly influenced by the outdoor temperatures, with annual span from around $10{ }^{\circ} \mathrm{C}$ to nearly $35{ }^{\circ} \mathrm{C}$. The regression coefficients ( 0.7479 for HSCW and 0.7394 for HSWW) further reflected that the indoor thermal environments are much sensitive and closely equal to outdoor thermal environments. This is partly due to the poor buildings performance (e.g., poor insulation of building envelope and infiltrations) and occupant behavior (residents in these regions likes to open windows even in the winter), which would have significant effect on occupants' thermal comfort. In particular, in the HSCW zone sometimes in winter the indoor air temperature could be even under $8^{\circ} \mathrm{C}$, which is far lower than the recommended set-point temperature range of 
$18^{\circ} \mathrm{C}$ to $24^{\circ} \mathrm{C}$ for heating prescribed by the standard[29]. For the $\mathrm{M}$ zone, being similar to that in Table 3, the annual indoor temperature mostly fluctuates in the range of $18{ }^{\circ} \mathrm{C}$ to $26^{\circ} \mathrm{C}$ when outdoor temperature is in the range of $15{ }^{\circ} \mathrm{C}$ to $25^{\circ} \mathrm{C}$, which were well in the comfort zones of heating and cooling recommended in the standard[29], thus showing little variations

278 throughout the year.
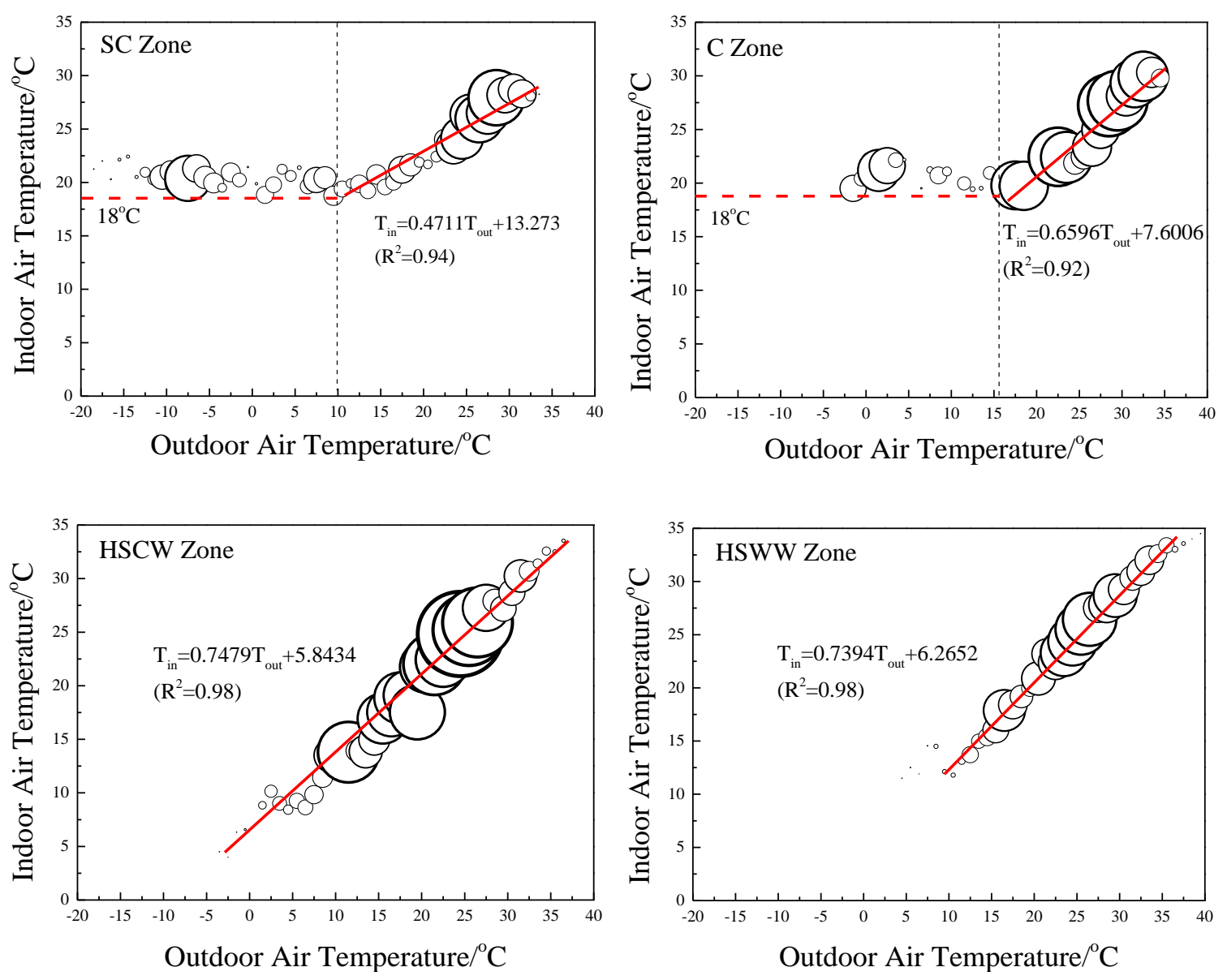


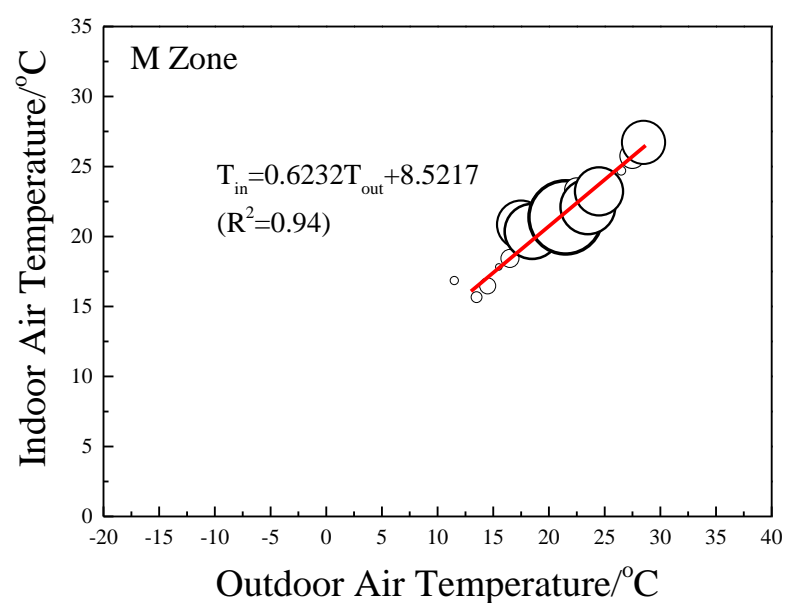

283 Figure 1. Relationship between indoor and outdoor air temperatures in the five climate zones

286 Occupants' thermal sensation of the thermal environment they are exposed to is essential in 287 evaluating indoor thermal comfort conditions[16]. Figure 2 shows the change of subjects' 288 mean thermal sensation votes (TSV) in responding to each bin of indoor air temperatures in 289 the five zones. In Figure 2, the recommended cooling and heating comfort zones for Grade I 290 and Grade II referring to the standard GB 50736[29] have been plotted with different grey 291 patches (light grey: Grade I; dark grey: Grade II).
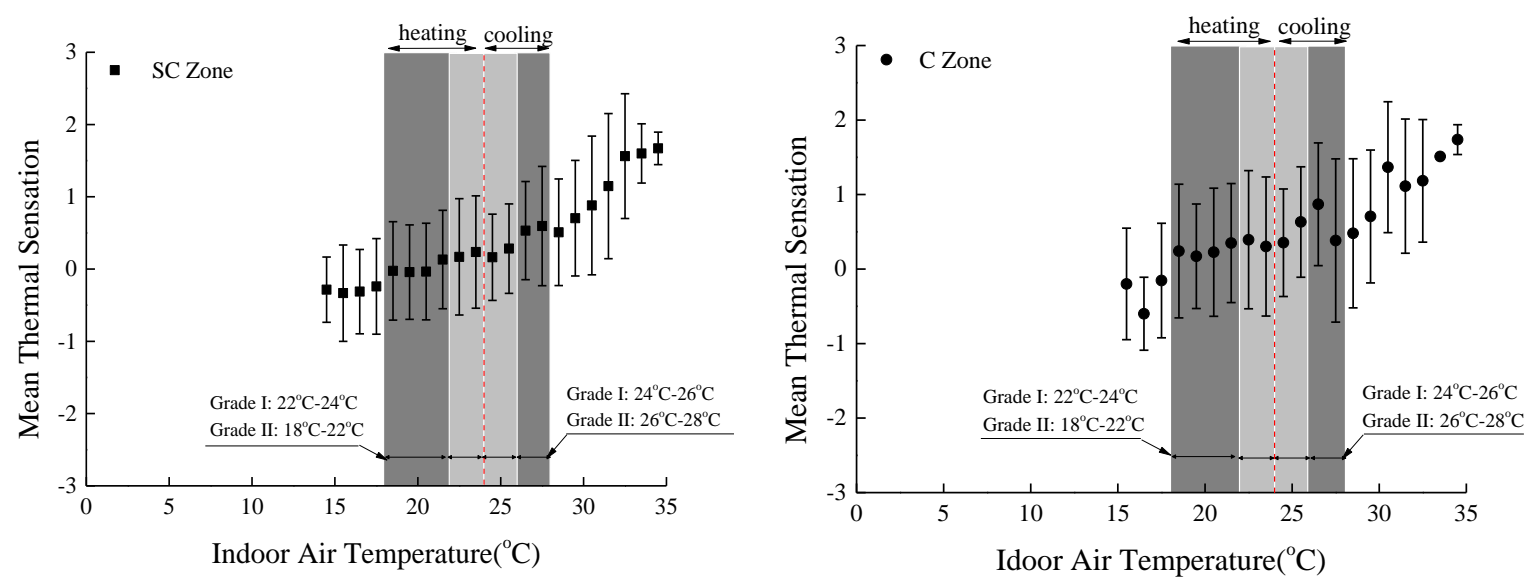

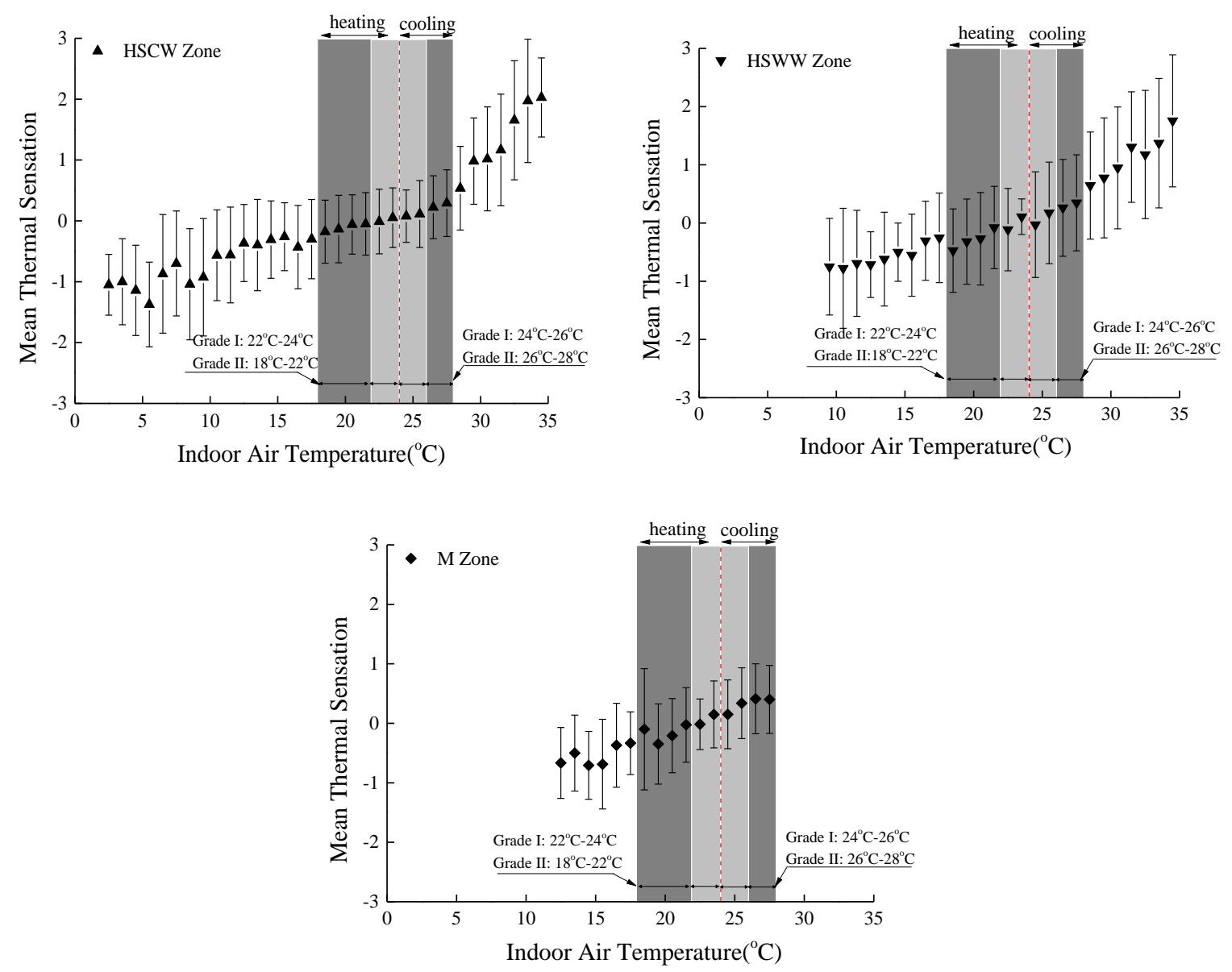

Figure 2. Mean TSV as a function of indoor air temperature

From the analysis of Figure 2, it can be seen that due to occupants' sensitivity differences with respect to air temperature, the variation trend of the mean TSV differed in different temperature intervals. Indeed, whatever the climate zone is, the mean TSV fluctuated around 0 and changed slightly within the temperature range from $18^{\circ} \mathrm{C}$ to $26^{\circ} \mathrm{C}$, showing a weak thermal response of the occupants in the comfort zone. When the indoor temperature was beyond the comfort zone, the mean TSV started varying significantly, especially for the warmest conditions $\left(\mathrm{T}_{\text {in }}>28^{\circ} \mathrm{C}\right)$. The TSV, taking the HSCW zone as an example, increases most significantly when the temperature is above $28^{\circ} \mathrm{C}$, and the increment is up to 0.56 when the temperature increases from $27.5^{\circ} \mathrm{C}$ to $30.5^{\circ} \mathrm{C}$, suggesting occupants are more sensitive to warm/hot environments. By contrast, the TSV variation is relatively smaller when the temperature decreases lower than 
$18{ }^{\circ} \mathrm{C}$, with TSV value decreased just by 0.01 from -0.3 at $17.5^{\circ} \mathrm{C}$ to -0.31 at 14.5 . Although the occupants' behavioral regulation are not involved in this study, we inferred that the less sensitivity of occupants' TSV in the cold side region could be explained by the compensation due to occupants' behavioral regulation, especially clothing adjustments[30]. Whilst in summer, if the temperature is high, the most used clothing regulation is less useful and the cooling efficiency of air movement is far from enough, so that the TSV increases significantly with temperatures. However, for the $\mathrm{SC}, \mathrm{C}$ and $\mathrm{M}$ zones, the narrow indoor temperature ranges lead to the slight change of occupants' thermal sensation. That is to say, the values of TSV are mostly in the range of -1 (slightly cool) to +1 (slightly warm), meaning the occupants have higher satisfaction for indoor thermal environments.

To analyze the correlation between the occupants' thermal sensation and the annual air temperature, the linear regression models developed for each climate zone are shown in Equations (1-5). Indeed, the regression coefficients of the models quantify the occupants' thermal sensitivity to a unitary temperature change: as an example, it is concluded that people in HSWW zone are more sensitive to a temperature increase (slope: 0.1134) while the degree of sensitivity are close to each other among SC, C and HSCW zones (0.0976, 0.094, 0.0942 respectively). The value in $\mathrm{M}$ zone (0.0744) shows the indoor temperature change leads to the minimum change of occupants' thermal sensation. It seems to be explained that the moderate temperature fluctuations may impair people’ vigilance in the M zone (slope: 0.0744).
M Zone:
SC Zone:
$\mathrm{TS} \mathrm{V}=0.09 \times 7_{\mathrm{i}} \mathrm{G}_{\mathrm{a}} \underset{\mathrm{T}}{\mathrm{T}}$
$1.97^{2}=(\mathrm{R}$
C Zone:
$T S V=0.0 \otimes 4_{i n} T_{i}-$
$1.79^{2}=(\mathrm{R}$
HSCW Zone:
$\mathrm{TSV}=0.0942_{\mathrm{n}} \mathrm{T}_{\mathrm{r}}^{-}$
$1.74^{2}=(\mathrm{R}$
HSWW Zone:
$\mathrm{TSV}=0.118_{\mathrm{i}+\mathrm{a}}^{\mathrm{T}} \mathrm{r}_{-}^{-}$
$2.38^{2}=(\mathrm{R}$ 
Here to note, Humphreys [31] in the field study of adaptive thermal comforts developed the regression methods between the occupants' comfort temperatures and the outdoor temperatures, which showed the occupants' comfort temperatures would be changed with outdoor air temperatures. The method is widely adopted and used by later researchers to get the neutral temperatures in different regions[16, 24, 32-34] . Among these studies, the typical adaptive coefficients are 0.31/K in ASHRAE 55[16] and 0.33/K in EN15251[24]; for others, all the coefficients are more than 0.1 , due to the remarkable fluctuation of outdoor temperatures and its indirect impact on human thermal sensation. By contrast, many field studies carried out worldwide have found that indoor temperature is the determinant factor of thermal sensation[20,35]. Therefore, here in this study, we built the direct relation between occupants' thermal sensation and indoor air temperatures, rather than the relation between comfort/neutral temperature and outdoor temperatures. From the obtained models in Equations (1-5), the TSV of occupants can be easily predicted for a given indoor temperature and conversely the acceptable temperature ranges and the neutral temperatures can be calculated if the TSV was determined.

\subsection{Thermal acceptability of indoor environments}

One of the most important purposes of thermal comfort studies is to 'determine the thermal environmental conditions in a space that are necessary to achieve acceptance by a specified percentage of occupants '[16]. Therefore, it is critical to specify the relationship between thermal sensation and thermal acceptability. In Figure 2, it shows the change of TSV with indoor temperatures but it fails to give the proportions of occupants' TSV in responding to each scale, especially in the range of -1 to 1 . Actually during the analysis, the majority of occupants' TSV were in the range of -1 to 1 , even though the thermal environments were beyond the comfort zones. Given this, the actual percentage of dissatisfied(APD) is a good metric to judge whether occupants are satisfied or dissatisfied with the thermal environments they are exposed. Since 'acceptability' is not precisely defined by standards[16, 36], in this paper the commonly used concept of 'acceptable' as a synonym of 'satisfaction' is used, being the 'satisfaction' more closely related to the thermal sensations of 'slightly warm $(+1)$ ', 
'neutral(0)', and 'slightly cool(-1)'.

By using this definition, the relationship between occupants' mean thermal sensation and percentage of dissatisfied have been investigated by means of the following steps:

1) The actual percentage of dissatisfied (APD), defined as the percentage of votes outside the comfortable thermal sensation range $(-1 \leq \mathrm{TSV} \leq 1)$ at a given indoor air temperature, is first calculated by Equation (6):

$$
A P D=X / Y \times 100 \%
$$

Here $\mathrm{X}$ is the total number of ASHRAE sensation votes outside of comfort (i.e. $-3,-2,2$ and 3) in a temperature bin while $\mathrm{Y}$ is the total number of sensation votes in that bin.

2) The corresponding Predicted Percentage of Dissatisfied (PPD) in each bin is calculated according to Fanger's PPD model [37] (Equation (7)):

$$
P P D=100-95 \exp \left[-\left(0.003353 T S V^{4}+0.2179 T S V^{2}\right)\right]
$$

where TSV is the subjects' mean thermal sensation votes in the corresponding bin.

Figure 3 shows the distribution of the predicted PPD using PMV-PPD and the real APD calculated according to respondents' thermal sensation votes. It is interestingly seen that in the two northern zones, because the majority of TSV values are bigger than 0 , the majority of scatters are found in the right part of horizontal axis. This is partly due to central heating systems in operation during winter (Figure 1), and it is consistent with what shown in Figure 2 about the variation of TSV with indoor temperatures. By contrast, in HSCW and HSWW zones the APD is more symmetric since TSV fluctuates in a respectively larger range. In particular, the APD was lower than $20 \%$ in most cases with TSV of -1 to 1 , and increased sharply when the TSV increased, especially from 1 to 2 . It should be explained here, though the occupants' mean TSV in Figure 2 changed in a wide range, the proportion beyond -1 and 1 were small, leading to the relatively lower APD in Figure 3. It is therefore not contradictory and reminds that it had better use more than one metric when evaluating human thermal comfort. 
Overall, except for the M zone where the average APD is lower than PPD, the occupants' APD in the other four zones is very close to the predicted PPD that the APD fluctuates around the predicted PPD and shared a similar trend, especially when the TSV is in the range of -2 to 2 . It is therefore confirmed that the PPD model can be successfully applied to residential buildings to elaborate the relationship between percentages of people who are dissatisfied against the mean TSV expressed by the same occupants.

390
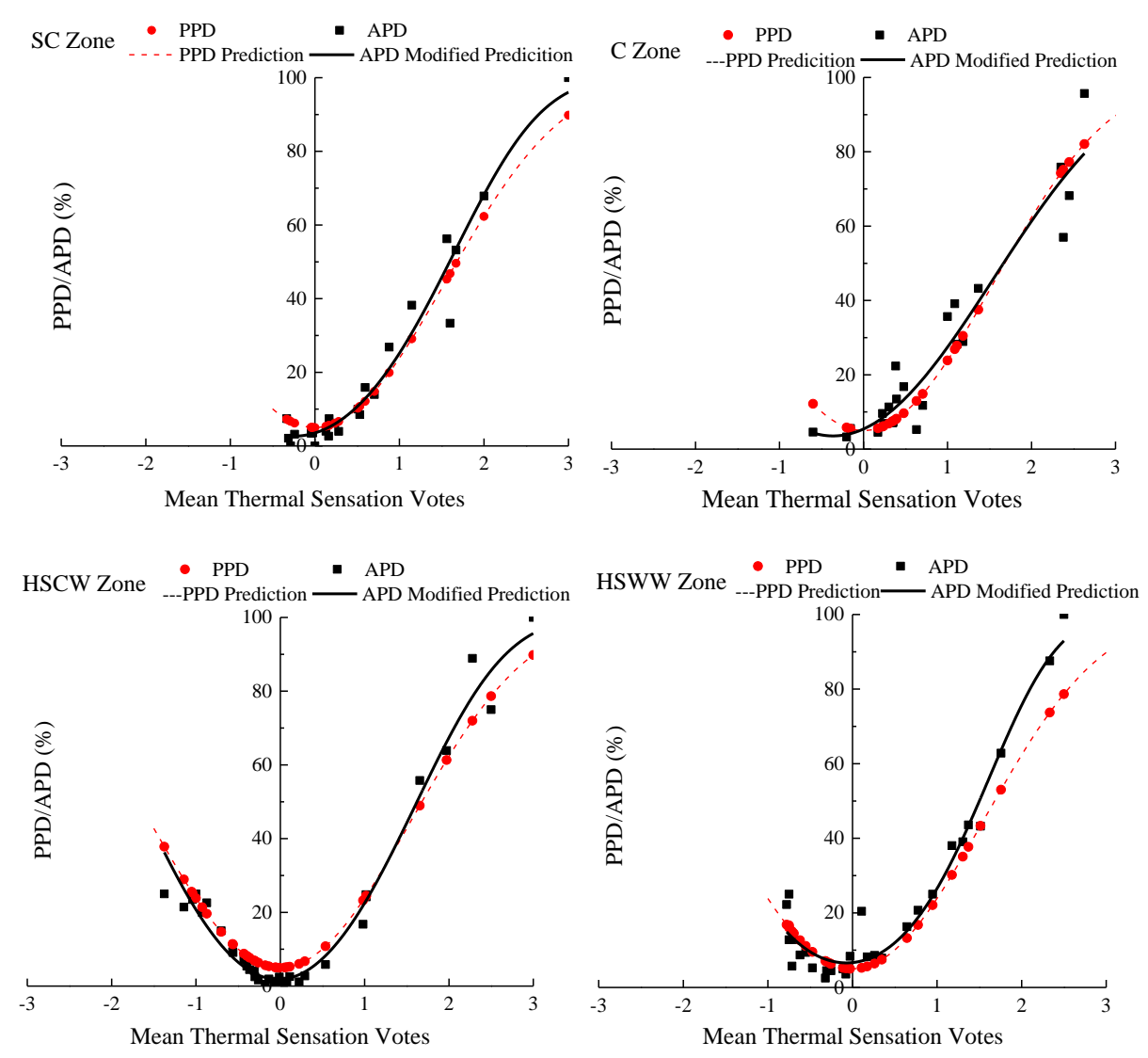


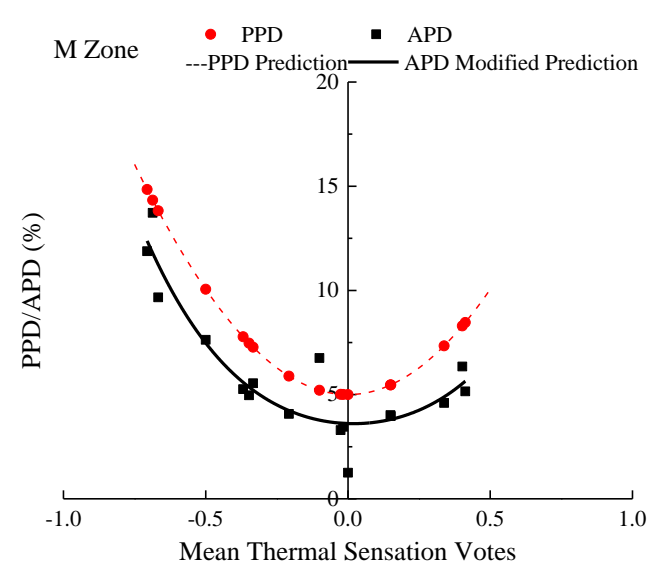

In order to better fit the prediction, we referred to Fanger's PPD model, which is expressed by 398 Equation (7). The regression coefficients $a, b, c$ and $d$ for each climate zone are listed in Table 3 together with the corresponding coefficient of determination $R^{2}$.

The best-fit curves obtained by using Equation (8) have been plotted in Figure 3 as black lines, compared to the PPD models. This relationship is very important for thermal comfort studies as it is usually regarded as a premise for developing adaptive models[22, 38]. For its application, the resulting equations for each climate zone can be applied to derive the acceptable temperature ranges with given percentage of occupant acceptability, combined with the relationship between the mean thermal sensation and indoor air temperatures according to Equations (1-5) already presented above in this study.

Table 4. Coefficients of the regression analysis

\begin{tabular}{cccccc}
\hline Climate Zones & a & b & c & d & $\mathbf{R}^{\mathbf{2}}$ \\
\hline SC zone & 97.33 & 0.015 & -0.24 & 0.146 & 0.971 \\
& & & & & \\
C zone & 96.45 & 0.003 & -0.36 & 0.148 & 0.912
\end{tabular}




\begin{tabular}{cccccc} 
HSCW zone & 98.17 & 0.014 & -0.24 & 0.211 & 0.973 \\
HSWW zone & 93.41 & 0.033 & -0.07 & 0.171 & 0.956 \\
M zone & 96.40 & 0.115 & 0.02 & 0.121 & 0.831 \\
\hline
\end{tabular}

410

\subsection{Thermal Comfort Zones}

There are some deviations between the Predicted Mean Vote (PMV) and the actual Thermal Sensation Votes (TSV) in naturally ventilated residential buildings due to occupants' long term thermal adaptation to local climate[23, 39]. In such cases, the adaptive Predictive Mean Vote (aPMV) model provided by Yao[40], which takes into account of factors such as culture, climate and occupants' long-term thermal adaptation and has been adopted by Chinese standard GB/T 50785 [41], is recommended to define the comfort conditions here.

In this study it is envisaged to build the comfort zones for the five climate zones via the direct variables of temperature and relative humidity, differing from that of adaptive models in standards[16, 36, 41]. Therefore, an effort to transfer the subjective evaluation expressed by the aPMV method to objective temperature-relative humidity zones needs to be undertaken first.

By referring to the comfort zones in ASHRAE 55[16] and defined in GB/T 50785, first the aPMV in the range of -0.5 to +0.5 have been taken as boundaries of the comfort zone, which means that at least $90 \%$ people are satisfied with the thermal environments. Then, as the aPMV is a function of PMV (Equation (9)[40]) and $\lambda$, it is possible to reversely calculate the PMV for a given aPMV value in the specified range of -0.5 to +0.5 and $\lambda$.

$$
\mathrm{a} P M V=P M V /(1+\lambda \times P M V)
$$

The $\lambda$ in Equation (9) is the adaptive coefficients. The values for different zones can be gathered from the standard GB/T 50785[41]. For SC and C zones, the recommended adaptive coefficient $\lambda$ is 0.24 when PMV is above 0 and -0.5 when PMV is below 0 ; while for HSCW, 
HSWW and M zones, the coefficient of $\lambda$ is 0.21 when PMV is above 0 and -0.49 when PMV is under 0 . Accordingly, the obtained PMV ranges modified by human thermal adaptation are from -0.67 to 0.57 for SC and $\mathrm{C}$ zones, and from -0.66 to 0.56 for HSCW, HSWW and M zones.

Since that PMV model is the function of the four environmental parameters (temperature, relative humidity, air velocity, mean radiant temperature) and two individual parameters (clothing insulation and metabolic rate)[37], to get the relation between air temperature and relative humidity, the other four parameters should be as the known variables during the calculation. Based on the results from the field study, the mean air velocity, mean clothing insulation and the mean metabolic rates can be obtained for the five zones. However, the mean radiant temperature, not like the other three variables, is related to and change with air temperature. In general, there are three cases that may affect the radiant temperature: local heating and cooling, intrusion of short-wavelength radiation [28]. In CIBSE Guide A[42] when calculating the operative temperature, it pointed out that in well insulated buildings which are predominantly by convective means, the difference between air and the mean radiant temperatures is small. This was referred by Nicol et al. [43], who used the globe temperature $\left(\mathrm{T}_{\mathrm{g}}\right)$ as the operative temperature to study the deviation of the adaptive equations for thermal comfort in free running buildings. In this study, the investigated objects are freerunning residential buildings and the majority of thermal environments are naturally convected, even if they were heated in northern zones. As a result, here it is supported and reasonable to make an assumption that the mean radiant temperature was equal to the air temperature when analyzing the relation between air temperature and relative humidity. In this way, the unknown variables are reduced to air temperature and relative humidity under the given values of modified PMV, air velocity, clothing insulation metabolic rate (obtained from field survey) and the radiant temperature (equivalent way).

According to the method mentioned above, the resulting acceptable temperature limits can thus be calculated for different relative humidity levels, as shown in Table 5. The relative humidity values of $70 \%$ and $80 \%$ have been chosen as the upper limit here for the two northern 
zones and the three southern zones respectively, according to the survey results.

\begin{tabular}{cccccc}
\hline \multirow{2}{*}{ RH (\%) } & \multicolumn{5}{c}{ Temperature ranges $\left({ }^{\circ} \mathbf{C}\right)$} \\
\cline { 2 - 6 } & SC zone & C zone & HSCW zone & HSWW zone & M zone \\
\hline \multirow{2}{*}{30} & $19.36-30.15$ & $17.41-29.12$ & $18.42-28.63$ & $19.99-29.95$ & $21.45-27.56$ \\
50 & $19.16-29.92$ & $17.15-28.85$ & $18.10-28.52$ & $19.89-29.78$ & $21.32-27.48$ \\
50 & $18.89-29.84$ & $16.96-28.64$ & $17.85-28.32$ & $19.72-29.62$ & $21.05-27.32$ \\
70 & $18.62-29.58$ & $16.65-28.48$ & $17.72-28.12$ & $19.53-29.43$ & $20.91-27.09$ \\
& & & $17.67-27.90$ & $19.18-29.36$ & $20.75-26.78$ \\
& $18.47-29.32$ & $16.48-28.27$ & $17.54-27.69$ & $18.89-29.10$ & $20.40-26.59$ \\
\hline
\end{tabular}

It is found that the lower temperature limit in $\mathrm{C}$ zone is much smaller (nearly $2^{\circ} \mathrm{C}$ ) than that in SC zone in winter, while the opposite happens if considering the upper temperature limit in summer (around $1^{\circ} \mathrm{C}$ ), and this holds for every humidity value. For the three southern zones the differences of temperature boundaries obviously reflect the local climatic differences. As an example, the minimum and maximum indoor temperature limits in HSCW zone are lower than those of HSWW zone of about $1.81^{\circ} \mathrm{C}$ and $1.31^{\circ} \mathrm{C}$ respectively under $60 \% \mathrm{RH}$. By contrast, the $\mathrm{M}$ zone has the narrowest temperature ranges due to moderate outdoor and indoor climates, which results in weaker thermal acceptability of occupants. Table 5 highlights also that both the upper and lower temperature limits decrease by almost $1{ }^{\circ} \mathrm{C}$ when increasing relative humidity from $30 \%$ to $70 \% / 80 \%$ in the five zones, suggesting that humidity as well plays a role on determining thermal comfort. However, it should be stated that even though the effect is slight in comfort zone, the high air humidity could increase the risk of building moist, condensation and mold etc., and for human health, the humidity is still a key factor for building thermal environments. 
According to the calculated temperature limits reported in Table 5, the acceptable comfort zones and the measured real indoor thermal environments from the surveyed buildings are compared in the psychrometric charts shown in Figure 4. In particular, the cases for winter are distinguished with green scatters and the remained with black scatters.

It is possible to notice how in the majority of cases for the $\mathrm{SC}$ and $\mathrm{C}$ zones indoor thermal conditions are distributed either within the comfort zone or close to its limits: the proportions of cases being within the comfort zone account for $65.59 \%$ for SC zone and $84.18 \%$ for C zone. This can be partly explained by the limited sample size and months comparably as well as by the contribution of central heating systems. However, as marked in green scatter in Figure 4, the risk of overheating sometimes may occur, especially for buildings located in the $\mathrm{C}$ zone, since the indoor temperatures are inclined to higher ones of the limits.

Comparatively, in the HSCW and HSWW zones the indoor temperatures distribution span from around $5{ }^{\circ} \mathrm{C}$ to nearly $35^{\circ} \mathrm{C}$ and just a limited number of data are in the comfort zone (only $44.73 \%$ for HSCW zone and $40.41 \%$ for HSWW zone). In winter, though the comfort zones presented have taken into account of occupants' thermal adaptation based on modified PMV range, the majority of cases (grey scatters) are out of comfort zones, manifesting again the terrible indoor thermal environments. Besides, the typical climatic characteristics of hot and humid in summer and cold and humid in winter leads to the results that more measured data are distributed in the range of $80 \% \mathrm{RH}$ to $100 \% \mathrm{RH}$ in summer and $60 \% \mathrm{RH}$ to $80 \% \mathrm{RH}$ in winter.

Figure 4 shows also in the M zone, even though data for some cases are below the lower limit, the overall indoor thermal environments fluctuated in the moderate temperature ranges (from $15^{\circ} \mathrm{C}$ to $25^{\circ} \mathrm{C}$ ) that are acceptable for occupants more easily. This contributes to create better indoor thermal environments, since the majority of cases investigated are within the comfort zone $(57.82 \%$ out of the total).

Please note, the Figure 4 objectively demonstrates the comfort zones in the five climate zones using theoretical calculation and meantime considering the adaptive modification, and the real 
thermal environments conditions. It is not conflicting with the aforementioned analysis of subjective thermal perceptions that occupants have higher thermal acceptability with their

506 surrounding thermal environments. On the contrary, it manifests the indoor thermal environments are still needed to improve pertinently, especially for HSCW and HSWW zones.
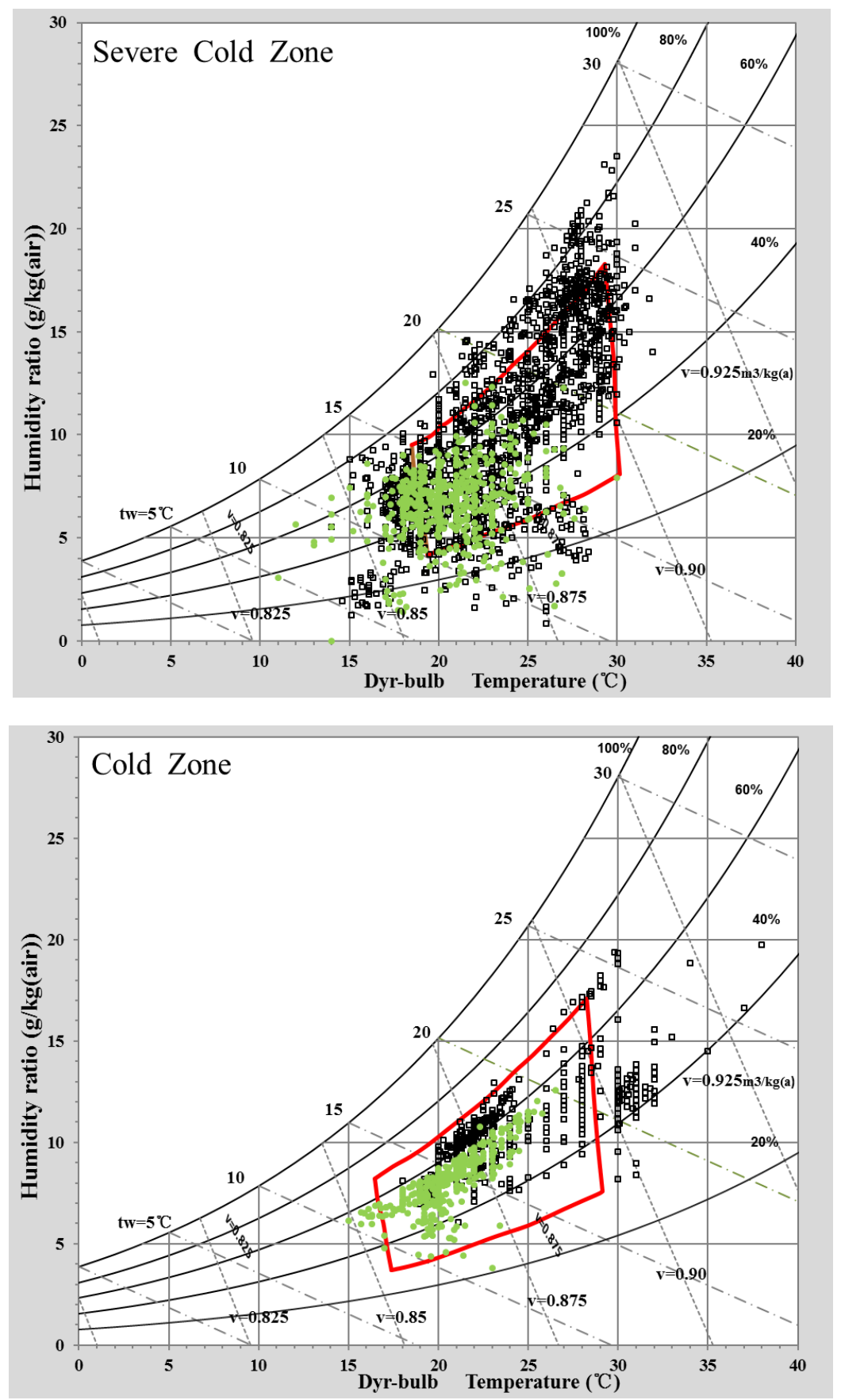

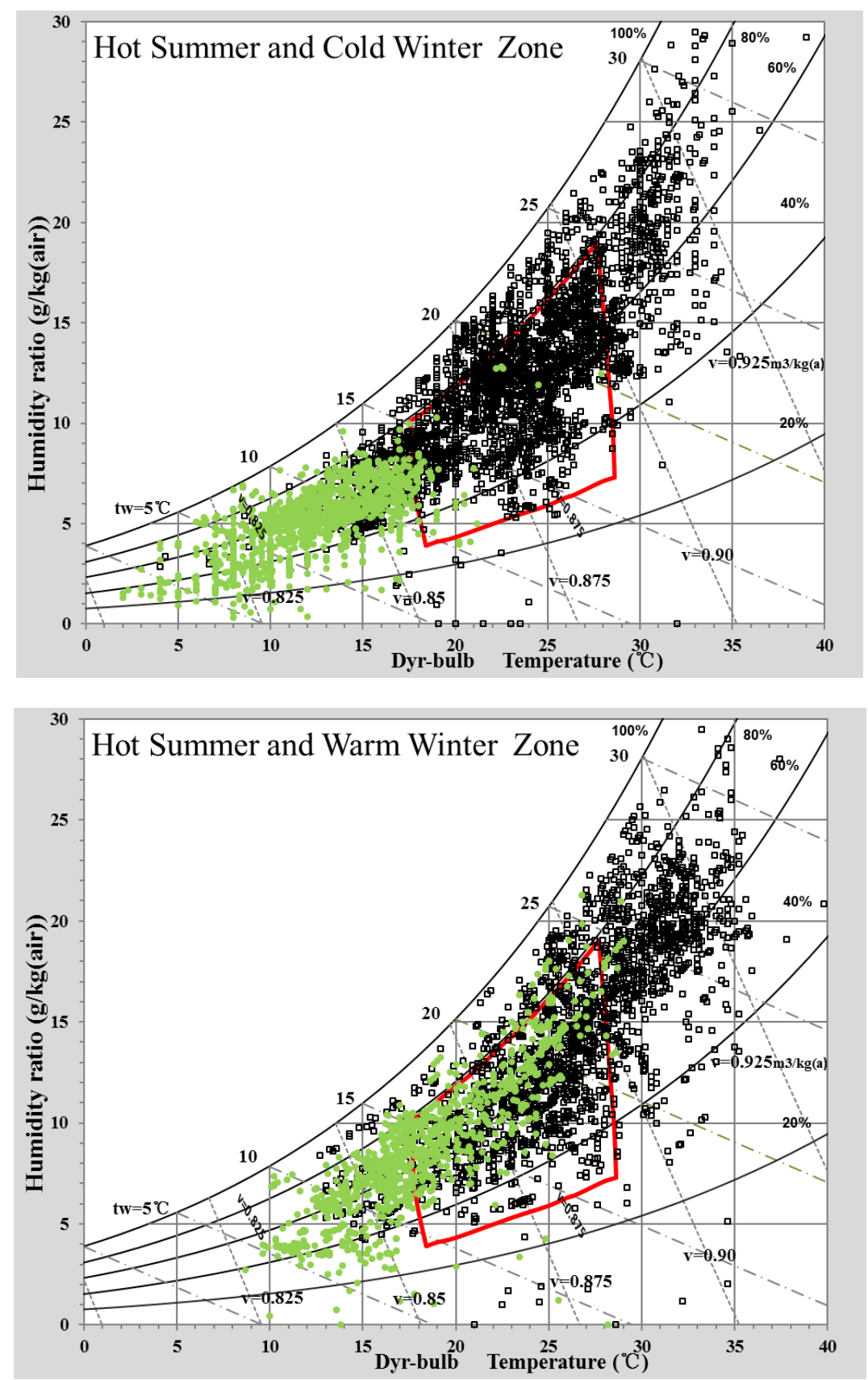


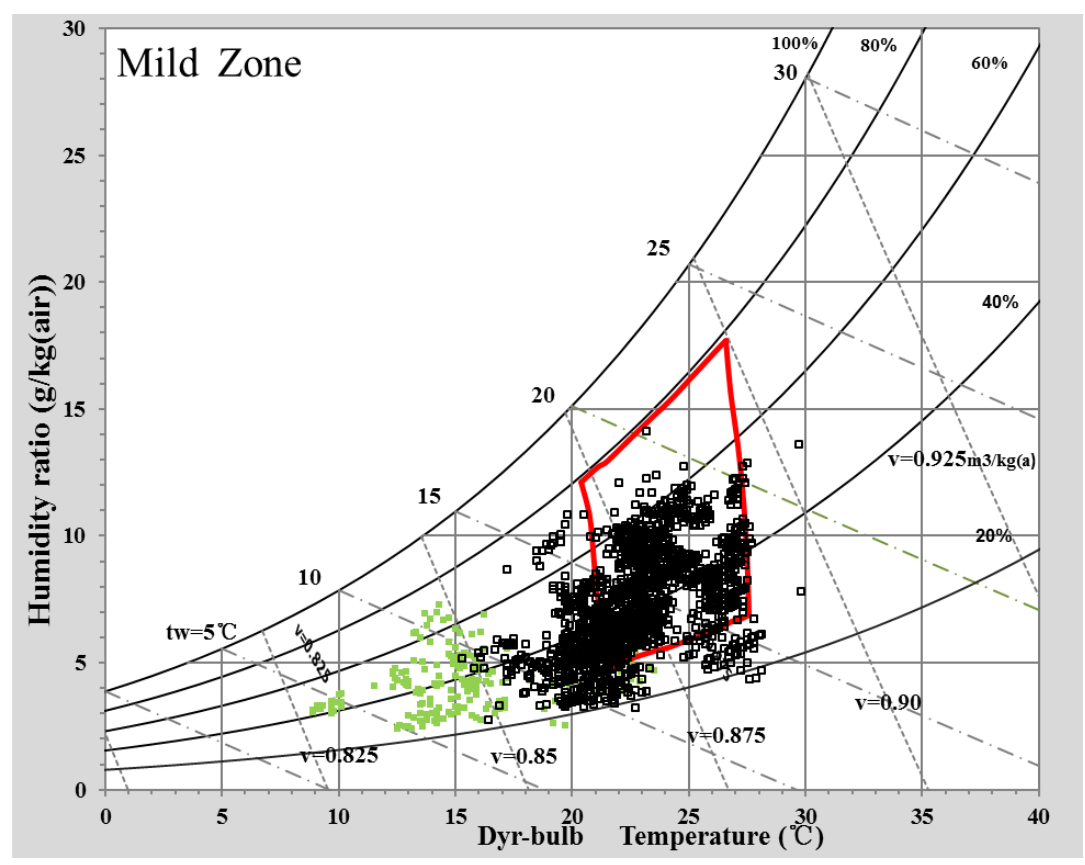

513 Figure 4. The acceptable comfort zones (red line polygons) of annual indoor temperatures in the five climate zones. Green dots: winter period samples. Black dots: all other periods' samples

Table 6 . The proportion of samples being within the thermal comfort zone yearly

\begin{tabular}{|c|c|c|c|c|c|}
\hline Climate zones & SC Zone & C zone & HSCW Zone & HSWW Zone & M Zone \\
\hline Total samples & 3040 & 1410 & 6154 & 3820 & 2034 \\
\hline $\begin{array}{l}\text { Samples in the } \\
\text { comfort zone }\end{array}$ & 1994 & 1187 & 2753 & 1544 & 1176 \\
\hline $\begin{array}{c}\text { \% of comfort } \\
\text { samples }\end{array}$ & 65.59 & 84.18 & 44.73 & 40.41 & 57.82 \\
\hline
\end{tabular}

\section{Discussion}

518 Analysis from above sheds light on the thermal environments characteristics for the five

519 climate zones and some of the main findings from the field study are here discussed more in 520 depth highlighting their potential implications for policy makers when taking decisions about 521 new regulations concerning buildings construction and operation. Generally speaking, the best 522 indoor comfort conditions have been found in the M zone (see Figure 1 and Figure 4) due to 523 the mild climate conditions, and thus the mechanical heating and cooling would be used just 
for few hours in a year. This means that no potential energy use increase for heating and cooling should be expected from buildings in this zone. Conversely, very different thermal environments have been found in the northern and southern zones of China that need to be analyzed more in detail for their implications on buildings energy consumption.

\subsection{Indoor thermal environments and their energy efficiency potential in the two northern} zones of China

As discussed above, the availability of central heating system in majority of residential buildings in SC and $\mathrm{C}$ zones makes wintertime indoor conditions comfortable for nearly $66 \%$ of time in SC zone and $84 \%$ of time in the $\mathrm{C}$ zone respectively. Figure 1 shows also that the indoor temperatures are always above $18^{\circ} \mathrm{C}$ regardless of the outdoor temperatures in winter, which is in agreement with Cao' studies[23]. Fortunately, according to the most recent Tsinghua Annual Report on China Building Energy Efficiency[3], though the total energy use for heating increases with the building areas increase in northern China, the energy consumption for heating per square meter has been reduced significantly by $34 \%$ from 2001 to 2014 , mainly due to improvements in buildings' envelope insulation, heating source forms and heating systems efficiencies. In this case, in these two northern zones, the further improvements of indoor thermal environments can be achieved by technical application and the increase of additional heating energy demand caused by new buildings can be moderately reduced.

As known, occupants' behavioral regulations are important factors for energy savings. However, what emerges from this survey is that the centrally-heated residential buildings investigated do not provide any control to occupants in terms of set-point temperatures or switching devices, which would predictably lead to energy waste and overheating issues (see Figure 1 and 4), especially for well-insulated envelopes. The 'over-heating' impels occupants to opening the windows to cool down rooms[44], or to dress with summer clothes, causing inevitably the additional energy waste. Unfortunately, the potential of energy saving caused by behavioral changes at present is difficult to quantify. It is generally assumed that behavioral changes could save between $10 \%$ and $30 \%$ in heating[45]. Based on this, the 
appropriate individual controls and behavior guides are the key points in these zones.

Therefore, what is suggested in these cold zones is mainly the use of passive heating techniques such as improving the envelope air tightness, coupled with efficient heating systems, as well as the management models such as household-based heating metering and flexible individualcontrols, to avoid the potential overheating issues. More importantly, it is worth considering that the set point of indoor air temperature for continuous heating should be changed dynamically during the heating periods. That is to say, the temperature set point can be slightly high in the early heating period, but it should be reduced in the mid-heating period due to the thermal storage in envelop, which would increase the mean radiant temperatures. In the lateheating period, coupled with the gradually increasing outdoor temperatures, the set point can be reduced further. As a result, the subdivision of heating periods and the stage-management of temperature set points are urgent to be solved for energy saving standards and policy making in northern China.

\subsection{Occupants' thermal adaptation for thermal environment design and appropriate} heating/cooling modes in south of China

The outcomes of this study highlights how the situation changes drastically in the two southern climate zones: here indoor thermal environments strictly follow outdoor conditions (see Figure 1) and are unbearably far away from comfort zone (Figure 4). Indeed, it is clearly seen that at least for half of the time the thermal environments could not meet comfort requirements in these regions. Especially in winter, there is a huge gap of indoor temperatures compared to northern zones. Comfort conditions account only for $5 \%$ of the time in the HSCW zone and for $34 \%$ of time in the HSWW zone in winter, well distant from the values set by the relevant standards[16, 29, 36, 41]. As a result, the thermal environment improving seems to take the first place in these two southern regions.

However, the improvements of thermal environments in HSCW and HSWW zones have posed great pressure on energy consumption, especially for HSCW zone, where the heating and cooling demand are both existed. In fact, according to the urban residential building energy 
use analysis[46], the occupants' expectations to improve their living standards in HSCW zone have already increased the number of standalone heating devices used, with a dramatic growth of 4.4 times in the heating energy consumption from 2001 to 2011. Though presently energy consumption for heating in residential areas is relatively low, the heating system penetration rate is predicted to soar in the next years because of the rapid urbanization rate and growing people's living standard expectations[47], and thus it will significantly affect any effort to control the total energy consumption of China[48].

However, from the view of thermal adaptation of occupants who have been in free running conditions for a long time, the challenge resulting from the increasing energy demand would be alieved to some degree. From the study, although the indoor thermal environments are poor (Figure1), the APD of the majority cases with the TSV changing mainly in the range of -1 to 1 is lower than $20 \%$, meaning that occupants have relatively high thermal satisfaction with thermal environments (Figure 3). This suggests that occupants who have been acclimatized to the local climate for a long time would have stronger thermal tolerance and weaker sensitivity to temperature variations[13, 19-21]. More importantly, the long-term physiological acclimatization of occupants may persist even when heating facilities are introduced into their built environments[49]. Besides, apart from physiological adaptation, psychological adaptation also plays an important role in determining occupants' thermal satisfaction: in fact, occupants would lower their psychological expectation on thermal environments if they realize they are unable to change but to accept it[19]. In our survey occupants' APD of indoor thermal environments were mainly under 20\% (see Figure 3) in response to TSV changes, meaning that although indoor environments deviate from neutral conditions, occupants have been accustomed to such environments[13,21]. As a result, the thermal adaptation would relieve the discomfort caused by temperature deviation and widen the acceptable temperature ranges of occupants. That is to say, it is possible to build the indoor temperature design to the slight cold side in winter and the slight hot side in summer[50] in these zones.

Figure 5 shows the comparisons of the two comfort zones calculated by the predicted PMV model and the modified PMV model using the aPMV method with the same prerequisites. It 
607

608

609

610

611

612

613

614

615

616

617

618

619

620

621

622

623

624

625

626

is clearly seen the thermal adaptation extends the comfort zones, especially in the cold sides.

The differences of the lower limits of temperatures are up to $1.76^{\circ} \mathrm{C}$ for $\mathrm{HSCW}$ zone and $1.36^{\circ} \mathrm{C}$ for $\mathrm{HSWW}$ zone at $30 \% \mathrm{RH}$. This means if the heating is available in winter in residential buildings, the design set point of temperature could be $1.76^{\circ} \mathrm{C}$ and $1.36^{\circ} \mathrm{C}$ lower respectively than the values recommended in the present standards, without compromising occupants' thermal comfort, which further supports the study by[49]. On the other hand, the extension of comfort zones would shorten the heating and cooling periods in these zones. This extends the non-HAVC period in transient seasons and provides great potential of building energy saving; meantime reduces energy demand of HAVC systems during the improvement of thermal environments in HSCW and HSWW zones.
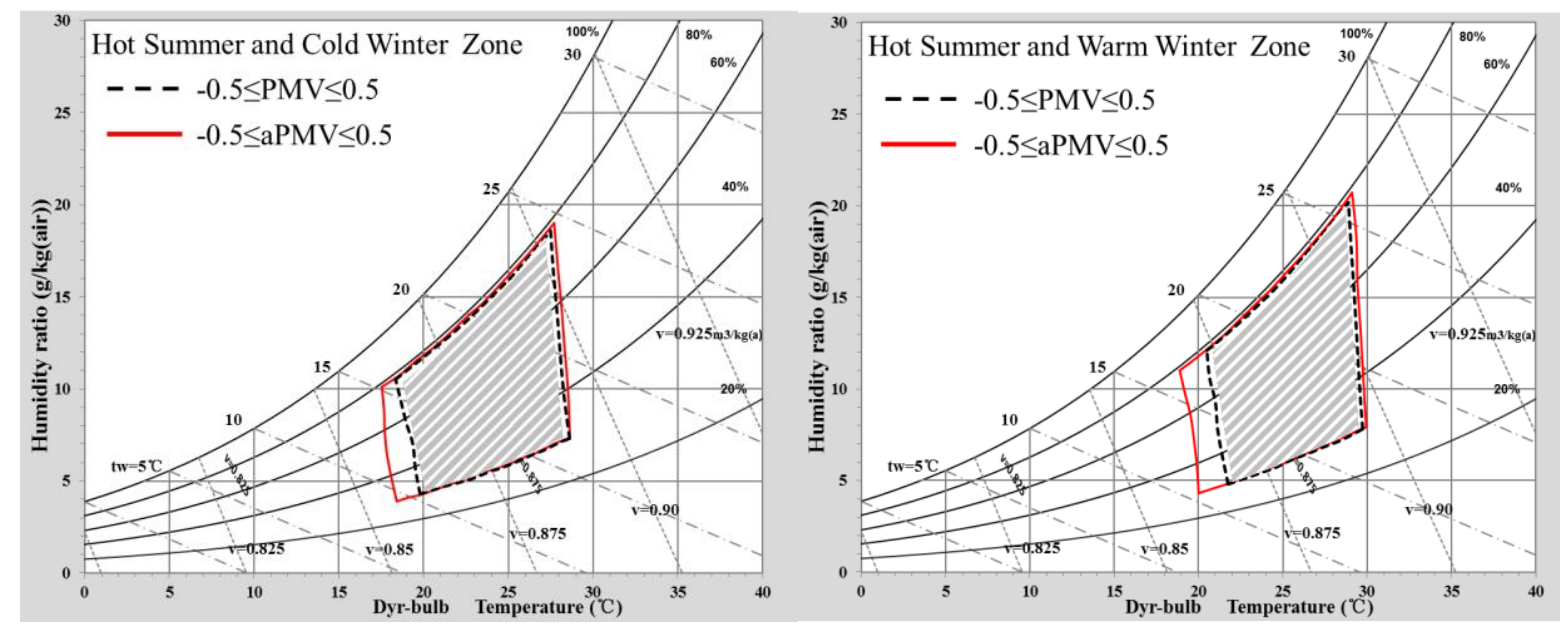

Figure 5 Comparisons of the comfort zones with PMV and modified PMV using aPMV method in HSCW and HSWW zones

Except the thermal environment design, the appropriate models for heating and cooling have being the focus in these zones. Considering the building performance and climatic characteristics, the outcomes of this study supports the statement for which part-time-partspace heating is able to provide comfortable indoor thermal environments, and meantime is much more energy efficient than the full-time-full-space heating used in HSCW zone[51]. It 
is highly recommended to develop diversified decentralized heating system[48] (e.g. airsource heat pump technology, solar energy, capillary radiant panels) to enhance the heating/cooling system efficiencies in this zone. In the meantime, studies on occupants' habits in this zone[21, 52, 53] should be of equal importance, in order to guide households towards energy-conserving behaviors[54].

\section{Conclusions}

A precedent large-scale survey on annual indoor thermal environments and comfort conditions in residential buildings has been conducted in the five climate zones of China (Severe Cold, Cold, Hot Summer and Cold Winter, Hot Summer and Warm Winter and Mild) in China. It forms a database with about 16500 sets of data for free-running buildings that has been discussed in this paper.

The indoor thermal environments in residential buildings show significant differences across the country. In northern China (i.e. Severe Cold (SC) and Cold (C) zones), the indoor thermal conditions in winter are weakly affected by outdoor climates and maintained above $18^{\circ} \mathrm{C}$ because of the use of central heating systems. As a consequence, the proportion of indoor temperatures falling in the comfort zone are high for the SC zone $(65.59 \%)$ and for the $\mathrm{C}$ zone $(84.18 \%)$. By contrast, the HSCW and HSWW zones have the least proportion of indoor temperatures falling in the comfort zone: $44.73 \%$ and $40.41 \%$ respectively due to the remarkable effect of outdoor climates. The mild climate of the Mild (M) zone contributes to a comfortable indoor thermal environment with a narrow temperature fluctuation from $18^{\circ} \mathrm{C}$ to $24^{\circ} \mathrm{C}$ all year round.

Despite the very different thermal environments, occupants have high thermal acceptability to indoor conditions thanks to long-term thermal adaptation. Indeed, the annual mean TSV of occupants is found to be mostly within the range from -1 to 1 for a wide range of temperatures, and show a different sensitivity according to different temperature ranges (it tends to vary in magnitude more easily for higher indoor temperatures rather than for low temperatures). The Actual Percentage of Dissatisfied (APD) models obtained by modification of Fanger's PPD 
model, prove to well-match with the change of the mean TSV, indicating the lower dissatisfaction of occupants with thermal environments (APD being under 20\%).

By combining the occupants' thermal adaptation to local climates, the comfort zones based on the adaptive Predictive Mean Vote (aPMV) and the PMV are drawn in the five zones. The resulting temperature ranges differ for different climate zones as well as for relative humidity levels, and are differed due to residents' long-term physiological and psychological adaptation.

This research provides comprehensive knowledge of the current situation of the indoor thermal environments and occupants' thermal perception and adaptation in the five different climate zones which can benefit research communities in studying climate responsive solutions to heating and cooling in order to satisfy the dual targets of thermal comfort and energy conservation. Furthermore, the research findings provide evidence to the building energy policy-makers the need of climate-occupant-responsive design standards for residential buildings in different regions in China.

\section{Acknowledgements}

The research work is supported by the Natural Science Foundation project of China (Grant No: NSFC 51561135002) and the UK Engineering and Physical Sciences Research Council (EPSRC EP/N009797/1). The research findings will support the National Key R\&D Programme 'Solutions to Heating and Cooling of Building in the Yangtze River Region' (Grant No: 2016YFC0700301). Miss Du would like to thank the finance support from the Graduate Scientific Research and Innovation Foundation of Chongqing, China (No. CYB16007).

\section{References:}

[1] IEA, Transition to sustainable buildings : strategies and opportunities to 2050. International Energy Agency, 2013.

[2] IEA, Modernising Building Energy Codes. International Energy Agency, 2013.

[3] Tsinghua University Building Energy Research Center, 2016 Annual Report on China Building Energy Efficiency. Energy Efficiency, China Architecture \& Building Press, Beijing, 2016. 
[4] U. Berardi, A cross-country comparison of the building energy consumptions and their trends, Resources Conservation \& Recycling. 123(2017)230-241.

[5] R. Yao, B. Li, K. Steemers, Energy policy and standard for built environment in China, Renew Energ. 30(13)(2005)1973-1988.

[6] NRDC (National Development and Reform Commission of Peoples' Republic of China), Enhanced Actions on Climate Change: China's Intended Nationally Determined Contribution, Beijing, 2015.

[7] B. Li, R. Yao, Building energy efficiency for sustainable development in China: challenges and opportunities, Build. Res. Inf. 40(4)(2012)417-431.

[8] B. Li, R. Yao, Q. Wang, Y. Pan, An introduction to the Chinese Evaluation Standard for the indoor thermal environment, Energ Buildings. 82(82)(2014)27-36.

[9] M.A. Mcneil, W. Feng, S.D.L.R. Can, N.Z. Khanna, J. Ke, N. Zhou, Energy efficiency outlook in China' s urban buildings sector through 2030, Energy Policy. 97(2016)532-539.

[10] CPC Central Committee and State Council, 'Healthy China 2030' Plan, 2016.

[11] GB 50178, Standard of Climate Regionalization for Architecture(in Chinese), Beijing: Chinese Plan Publication House, China, 1993.

[12] H. Yoshino, Y. Yoshino, Q. Zhang, A. Mochida, N. Li, Z. Li, H. Miyasaka, Indoor thermal environment and energy saving for urban residential buildings in China, Energ Buildings. 38(11)(2006)1308-1319.

[13] Y. Zhang, J. Wang, H. Chen, J. Zhang, Q. Meng, Thermal comfort in naturally ventilated buildings in hothumid area of China, Build Environ. 45(11)(2010)2562-2570.

[14] Z. Wang, L. Zhang, J. Zhao, Y. He, Thermal comfort for naturally ventilated residential buildings in Harbin, Energ Buildings. 42(12)(2010)2406-2415.

[15] B. Cao, Y. Zhu, Q. Ouyang, X. Zhou, M. Luo, Indoor thermal environment and human thermal adaptation in residential buildings in various climate zones during the winter, Journal of Tsinghua University. 52(2012)499502.

[16] ASHRAE 55, Thermal Environmental Conditions for Human Occupancy, in: American Society of Heating, Ventilating and Air-Conditioning Engineering Inc, Atlanta, US, 2013.

[17] J. Han, G. Zhang, Q. Zhang, J. Zhang, J. Liu, L. Tian, C. Zheng, J. Hao, J. Lin, Y. Liu, Field study on occupants' thermal comfort and residential thermal environment in a hot-humid climate of China, Build Environ. 42(12)(2007)4043-4050.

[18] H. Yan, Y. Mao, L. Yang, Thermal adaptive models in the residential buildings in different climate zones of Eastern China, Energ Buildings. 141(2017)28-38.

[19] J. Yu, G. Cao, W. Cui, Q. Ouyang, Y. Zhu, People who live in a cold climate: thermal adaptation differences based on availability of heating, Indoor Air. 23(4)(2013)303-310.

[20] M. Luo, W. Ji, B. Cao, Q. Ouyang, Y. Zhu, Indoor climate and thermal physiological adaptation: Evidences from migrants with different cold indoor exposures, Build Environ. 98(2016)30-38.

[21] B. Li, M. Tan, H. Liu, X. Ma, W. Zhang, Occupant's Perception and Preference of Thermal Environment in Free-running Buildings in China, Indoor Built Environ. 19(4)(2010)405-412.

[22] R. Yao, J. Liu, B. Li, Occupants' adaptive responses and perception of thermal environment in naturally conditioned university classrooms, Appl Energ. 87(3)(2010)1015-1022.

[23] B. Cao, M. Luo, M. Li, Y. Zhu, Too cold or too warm? A winter thermal comfort study in different climate zones in China, Energ Buildings. 133(2016)469-477.

[24] EN 15251 Indoor Environmental Input Parameters for Design and Assessment ofEnergy Performance of Buildings-addressing Indoor Air Quality, Thermal Environment, Lighting and Acoustics, in: European 
Committee for Standization, Brussels, 2007.

[25] JGJ 134. Design standard for energy efficiency of residential buildings in hot summer and cold winter zone(In Chinese), in: MOHURD, Beijing, 2001.

[26] JGJ 134. Design standard for energy efficiency of residential buildings in hot summer and cold winter zone(In Chinese), in: MOHURD, Beijing, 2010.

[27] ISO 9920. Ergonomics of the thermal environment-Estimation of thermal insulation and water vapour resistance of a clothing ensemble, in: International Organization for Standardization, 2007.

[28] ISO 7726. Ergonomics of the thermal environment-Instruments for measuring physical quantities, in: International Organization for Standardization, 2001.

[29] GB 50736. Design code for heating ventilation and air conditioning of civil buildings(In Chinese), Beijing: China Architecture and Building Press, 2012.

[30] A.K. Mishra, M. Ramgopal, Field studies on human thermal comfort-An overview, Build Environ. 64(3)(2013)94-106.

[31] M.A. Humphreys, Field Studies of Thermal Comfort Compared and Applied. 1976

[32] K.J. Mccartney, J.F. Nicol, Developing an adaptive control algorithm for Europe, Energ Buildings. 34(6)(2002)623-635.

[33] X. Su, X. Zhang, J. Gao, Evaluation method of natural ventilation system based on thermal comfort in China, Energ Buildings. 41(1)(2009)67-70.

[34] X.J. Ye, Z.P. Zhou, Z.W. Lian, H.M. Liu, C.Z. Li, Y.M. Liu, Field study of a thermal environment and adaptive model in Shanghai, Indoor Air. 16(4)(2010)320-326.

[35] J.F. Nicol, M.A. Humphreys, Adaptive thermal comfort and sustainable thermal standards for buildings, Energ Buildings. 34(6)(2002)563-572.

[36] ISO 7730. Ergonomics of the thermal environment -Analytical determination and interpretation of thermal comfort using calculation of the PMV and PPD indices and local thermal comfort criteria, in: International Organization for Standardization, 2005.

[37] Fanger. PO, Thermal comfort-Analysis and applications in environmental engineering., Copenhagen, 1970.

[38] R. De Dear, Developing an adaptive model of thermal comfort and preference, ASHRAE Trans. 104(1)(1998)73-81.

[39] G.S. Brager, R.J.D. Dear, Thermal adaptation in the built environment: a literature review, Energ Buildings. 27(1)(1998)83-96.

[40] R. Yao, B. Li, J. Liu, A theoretical adaptive model of thermal comfort-Adaptive Predicted MeanVote(aPMV), Build Environ. 44(10)(2009)2089-2096.

[41] GB/T 50785. Evaluation standard for indoor thermal environment in civil buildings(In Chinese), Beijing: China Architecture and Building Press, 2012.

[42] CIBSE Environmental Design. CIBSE Guide A, Chapter 1, Environmental criteria for design (revision), London: Chartered Institution of Building Services Engineers, London, 2006.

[43] F. Nicol, M. Humphreys, Derivation of the adaptive equations for thermal comfort in free-running buildings in European standard EN15251, Build Environ. 45(1)(2010)11-17.

[44] Z. Wang, Y. Ji, J. Ren, Thermal adaptation in overheated residential buildings in severe cold area in China, Energy \& Buildings. 146(2017) 322-332

[45] IPCC, Climate Change 2014: Mitigation of Climate Change, Chapter 9: Buildings. Intergovernmental Panel on Climate Change, 2014.

[46] Tsinghua University Building Energy Research Center, 2013 Annual Report on China Building Energy 
Efficiency. China Architecture \& Building Press, Beijing, 2013.

769 [47] Y. Liu, H. Yan, J.C. Lam, Thermal comfort and building energy consumption implications-A review, Appl 770 Energ. 115(4)(2014)164-173.

771 [48] S. Hu, D. Yan, Y. Cui, S. Guo, Urban residential heating in hot summer and cold winter zones of China772 Status, modeling, and scenarios to 2030, Energy Policy. 92(2016)158-170.

773 [49] Z. Wang, R.D. Dear, B. Lin, Y. Zhu, Q. Ouyang, Rational selection of heating temperature set points for 774 China's hotsummer-Cold winter climatic region, Build Environ. 93(2015)63-70.

775 [50] G. Baird, C. Field, Thermal comfort conditions in sustainable buildings-Results of a worldwide survey of 776 users' perceptions, Building Acoustics. 49(4)(2013)44-47.

777 [51] Z. Wang, B. Lin, Y. Zhu, Modeling and measurement study on an intermittent heating system of a residence 778 in Cambridgeshire, Build Environ. 92(2015)380-386.

779 [52] L. Jing, R. Yao, J. Wang, B. Li, Occupants' behavioural adaptation in workplaces with non-central heating 780 and cooling systems, Appl Therm Eng. 35(1)(2012)40-54.

781 [53] H. Liu, Y. Wu, B. Li, Y. Cheng, R. Yao, Seasonal variation of thermal sensations in residential buildings in 782 the Hot Summer and Cold Winter zone of China, Energ Buildings. 140(2017)9-18.

783 [54] J.L. Fan, H. Liao, Q.M. Liang, H. Tatano, C.F. Liu, Y.M. Wei, Residential carbon emission evolutions in 784 urban - rural divided China: An end-use and behavior analysis, Appl Energ. 101(1)(2013)323-332. 


\section{APPENDIX}

\section{First Part (for respondents)}

Sex: Male $\square$ Female $\square$, Age:

Height: Weight: Occupation :

Length of residence: year (s)

\begin{tabular}{|c|c|}
\hline $\begin{array}{l}\text { 1. Built time for present } \\
\text { buildings: }\end{array}$ & Before 70s $\square, 70 \mathrm{~s} \square, \quad 80 \mathrm{~s} \square, \quad 90 \mathrm{~s} \square$, new buildings $\square$ \\
\hline 2. Present dressing: & $\begin{array}{l}\text { upper : shirt } \square, \text { T-shirt } \square, \text { a suit and tie } \square \text {, thin coat } \square \text {, none } \square \\
\text { lower : trousers } \square, \text { shorts } \square, \text { dresses } \square, \text { skirts } \square, \\
\text { shoes : sneaker } \square, \text { leather shoes } \square, \text { sandals } \square, \text { slipper } \square, \\
\text { socks : socks(thin) } \square, \text { silk socks } \square, \text { none } \square, \\
\text { others : }\end{array}$ \\
\hline 3. Time spending in this room: & $\begin{array}{l}\text { morning } \square, \text { noon } \square, \text { afternoon } \square, \quad \text { evening } \square, \quad \text { all day } \square \\
\text { total hours : }\end{array}$ \\
\hline 4. Feeling at present : & $\begin{array}{l}\text { temperature: hot } \square, \text { warm } \square \text {, slightly warm } \square \text {, neutral } \square \text {, slightly } \\
\text { cool } \square \text {, cool } \square \text {, cold } \square \\
\text { humidity : too humid } \square \text {, humid } \square \text {, slightly humid } \square \text {, comfort } \square \text {, } \\
\text { slightly dry } \square \text {, dry } \square \text {, too dry } \square \\
\text { air movement: too stuffy } \square, \text { stuffy } \square \text {, slightly stuffy } \square \text {, comfort } \square \text {, } \\
\text { slightly windy } \square \text {, windy } \square \text {, too windy } \square\end{array}$ \\
\hline $\begin{array}{l}\text { 5. Thermal satisfaction at } \\
\text { present : }\end{array}$ & $\begin{array}{l}\text { dissatisfied } \square, \text { slightly dissatisfied } \square \text {, acceptable } \square \text {, slightly satisfied } \square \text {, } \\
\text { satisfied } \square\end{array}$ \\
\hline 6. If dissatisfied, the reason is : & $\begin{array}{l}\text { none } \square, \text { cold } \square, \text { hot } \square, \text { humid } \square, \text { dry } \square, \text { stuffy } \square, \text { draught } \square \text {, } \\
\text { others : }\end{array}$ \\
\hline $\begin{array}{l}\text { 7. Thermal expectation for } \\
\text { indoor thermal environments: }\end{array}$ & $\begin{array}{l}\text { temperature : } \text { upper } \square, \quad \text { no change } \square, \quad \text { lower } \square \\
\text { humidity : } \quad \text { upper } \square, \quad \text { no change } \square, \quad \text { lower } \square \\
\text { air velocity : } \quad \text { upper } \square, \quad \text { no change } \square, \quad \text { lower } \square\end{array}$ \\
\hline
\end{tabular}




\begin{tabular}{|c|c|}
\hline $\begin{array}{l}\text { 8. Which ways would you like } \\
\text { to improve individual thermal } \\
\text { comfort : }\end{array}$ & $\begin{array}{l}\text { Comfortable, no change } \square \text {, using air-conditioning } \square \text {, opening window } \\
\text { for ventilation } \square, \text { closing window } \square \text {,add clothing } \square \text {, take off } \\
\text { clothing } \square \text {, hot drinks } \square \text {, cool drinks } \square \text {, light activities } \square \text {, changing } \\
\text { postures } \square \text {, others : }\end{array}$ \\
\hline $\begin{array}{l}\text { 9. The habit, time and reasons } \\
\text { for window opening : }\end{array}$ & $\begin{array}{l}\text { Habits: frequently } \square, \quad \text { occasionally } \square, \quad \text { seldom } \square ; \\
\text { Time: morning } \square, \quad \text { noon } \square, \quad \text { afternoon } \square, \quad \text { evening } \square \text {; } \\
\text { Reasons: smoking } \square, \quad \text { stuffy } \square, \quad \text { ventilation } \square, \quad \text { lighting } \square\end{array}$ \\
\hline $\begin{array}{l}\text { 10. Do you use air- } \\
\text { conditioning frequently in } \\
\text { Summer: }\end{array}$ & $\begin{array}{l}\text { YES } \square, N O \square \text {; if it is no, please choose the reason: } \\
\text { (1)comfortable, no need } \square \text {, (2) unlike, draught } \square \text {, (3)poor air } \\
\text { circulation } \square \text {, (4)power saving } \square, \text { (5) using other regulation } \\
\text { methods } \square \text {, (6) without devices in rooms } \square\end{array}$ \\
\hline $\begin{array}{l}\text { 11. How are you feelings in the } \\
\text { room for a long time? }\end{array}$ & $\begin{array}{l}\text { Fatigue and drowsiness } \square \text {, nausea and dizzy } \square \text {, hot and upset } \square \text {, eyes } \\
\text { irritation } \square \text {, sore throat } \square \text {, nose discomfort and shortness of breath } \square \text {, } \\
\text { tinnitus } \square \text {, impaired concentration } \square \text {, dry, itchy and rash of skin } \square \text {, } \\
\text { none } \square\end{array}$ \\
\hline $\begin{array}{l}\text { 12. The overall thermal } \\
\text { acceptability for thermal } \\
\text { environments: }\end{array}$ & $\begin{array}{l}\text { absolutely unacceptable } \square \text {, unacceptably } \square \text {, slightly unacceptable } \square \text {, } \\
\text { slightly acceptable } \square \text {, acceptable } \square, \text { absolutely acceptable } \square\end{array}$ \\
\hline
\end{tabular}

\section{Second Part (for testers)}

City: Building name: Types of community: residences $\square$, downtown $\square$; others $\square$

Dates : $\mathbf{y y} \_\mathbf{m m}$ dd Time : Weather (sunny $\square$ cloudy $\square$ rain $\square$ snow $\square$ ）

795 Tester name :

\begin{tabular}{|l|l|}
\hline 1. Building structure : & $\begin{array}{l}\text { Masonry-concrete structure } \square, \text { Reinforced Concrete Structure } \square, \\
\text { others } \square\end{array}$ \\
\hline 2. Building location: & Along the street $\square$, away from street $\square$, suburb $\square$ \\
\hline 3. Total layers and floor : & Floor: $\_$total: $\quad$ (basement excluded) \\
\hline
\end{tabular}




\begin{tabular}{|c|c|}
\hline $\begin{array}{l}\text { 4. Window orientation for } \\
\text { measuring room : }\end{array}$ & $\begin{array}{l}\text { east } \square \text {, south } \square, \text { west } \square, \text { north } \square \text {, southeast } \square \text {, northeast } \square \text {, } \\
\text { southwest } \square \text {, northwest } \square\end{array}$ \\
\hline 5. Type of rooms : & Living rooms: \\
\hline 6. Room areas : & areas: $\mathrm{m}^{2}$, window (overall : $-\mathrm{m}^{2}$, opening areas \\
\hline 7. Types of windows : & $\begin{array}{l}\text { Single frame with single glass } \square \text {, single frame with double glass } \square \text {, } \\
\text { double frames with double glass } \square\end{array}$ \\
\hline $\begin{array}{c}\text { 8. The number of people } \\
\text { presently in room: }\end{array}$ & Number:_ \\
\hline $\begin{array}{l}\text { 9. Activities for } \\
\text { respondents : }\end{array}$ & reclining $\square$, sitting $\square$, standing $\square$, walking $\square$ \\
\hline $\begin{array}{l}\text { 10. The window condition } \\
\text { at present : } \\
\end{array}$ & open $\square, \quad$ close $\square$ \\
\hline $\begin{array}{l}\text { 11. The regulation method } \\
\text { for indoor thermal } \\
\text { environments at } \\
\text { present: }\end{array}$ & $\begin{array}{l}\text { Air-conditioning } \square, \text { household central air-conditioning } \square, \text { central } \\
\text { cooling } \square \text {, air conditioning fan } \square, \text { electric fan } \square, \text { naturally ventilation } \square, \\
\text { without regulation measures } \square, \text { others: }\end{array}$ \\
\hline $\begin{array}{l}\text { 12. Is the air-conditioning } \\
\text { opened ? if so, the set-point } \\
\text { is : }\end{array}$ & $\begin{array}{l}\text { Yes } \square \text {, No } \square \\
\text { Under } 20^{\circ} \mathrm{C} \square, 20^{\circ} \mathrm{C} \square, \quad 21^{\circ} \mathrm{C} \square, 22^{\circ} \mathrm{C} \square, 23^{\circ} \mathrm{C} \square, 24^{\circ} \mathrm{C} \square, 25^{\circ} \mathrm{C} \square, 26^{\circ} \mathrm{C} \square \text {, } \\
27^{\circ} \mathrm{C} \square, \geq 28^{\circ} \mathrm{C} \square, \quad \text { unclear } \square\end{array}$ \\
\hline
\end{tabular}

799 1. Test instrument type : Temperature and humidity meter : Anemometer :

801 3. Recording Table :

\begin{tabular}{|l|l|l|l|l|l|l|l|}
\hline Measuring times & 1 & 2 & 3 & $\begin{array}{l}\text { Indoor air } \\
\text { temperature }{ }^{\circ} \mathrm{C}:\end{array}$ & 1 & 2 & 3 \\
\hline
\end{tabular}




\begin{tabular}{|l|l|l|l|l|l|}
\hline $\begin{array}{l}\text { Outdoor air } \\
\text { temperature }{ }^{\circ} \mathrm{C}:\end{array}$ & & & $\begin{array}{l}\text { Indoor air } \\
\text { temperature }{ }^{\circ} \mathrm{C}:\end{array}$ & & \\
\hline $\begin{array}{l}\text { Outdoor relative } \\
\text { humidity \%: }\end{array}$ & & $\begin{array}{l}\text { Indoor relative } \\
\text { humidity \%: }\end{array}$ & & & \\
\hline $\begin{array}{l}\text { Outdoor air } \\
\text { velocity m/s : }\end{array}$ & & $\begin{array}{l}\text { Indoor air } \\
\text { velocity } \mathrm{m} / \mathrm{s}:\end{array}$ & & & \\
\hline
\end{tabular}

802

803 